\title{
The Political Psychology of Lynching: WhatsApp Rumors, Anti-Government Appeals, and Violence
}

\author{
Daniel Zizumbo-Colunga \\ Center for Research and Teaching in Economics \\ daniel.zizumbo@cide.edu \\ María del Pilar Fuerte-Celis \\ Centro GEO
}

Paper prepared for the 2020 Annual Meeting of the American Political Science Association

\begin{abstract}
Across the world, violence-inducing rumors about crime have triggered spectacular displays of violence. We argue that, in addition to other components, appeals to the untrustworthiness of government authorities constitute a central component of the DNA of violence-inducing rumors. Indeed, a component that allows those circulating rumors to persuade individuals of their credibility and importance. To test this hypothesis, we conducted an original laboratory experiment among students in a rural community in Mexico. We find evidence that appeals to the untrustworthiness of government increase citizens' perceptions of the credibility, importance and shareability of the message. Further, we find individuals perceiving rumors as more credible, important, and sharable to be more likely to incite others to commit violence against alleged criminals when given a chance. The results of this study have broad implications for our understanding of the psychology of rumor sharing and the emergence of extralegal violence.
\end{abstract}


On August 30 of 2018, hundreds of citizens in the small rural town of Acatlán, central Mexico, gathered to photograph, film, and share through social media something burning in front of the municipal police station. This story is true except for the fact that what they were filming was not something but someone. To be precise, it was Alberto Flores (43) and his nephew Ricardo (22), who moments before had been burned alive by an angry mob. The two innocent men had been falsely accused of kidnapping children and trafficking with their organs by citizens reading fake rumors in WhatsApp (Martínez 2018). This case is not unique. It is just one of the many incidents in which violence-inducing rumors circulating through Whatsapp, the largest messaging network in the world, have led to explosions of collective violence (Arun 2019; Comercio 2017; Farooq 2018; Martínez 2018; Miranda 2018; Smink 2019; Zerega 2019).

While the contextual and individual level forces that lead citizens to share misinformation have attracted the attention of social and computer scientists (Lazer et al. 2018), the sections of the DNA of rumors and fake news that make them infectious (capable of persuading) and contagious (capable of propagating) are relatively less well understood. We seek to contribute to the literature on the subject by arguing that rumors that contain appeals to the indifference and malevolence of government are more likely to persuade citizens that they are credible and important and, ultimately, increase their chances to propagate and incite collective violence.

To test this argument, we present an original (pre-registered) laboratory study in which we asked hundreds of citizens in a rural municipality not unlike Acatlán, to evaluate the credibility and importance of a WhatsApp Message known to be involved in different episodes of extralegal violence and indicate whether they would share it among their contacts. ${ }^{1}$ We manipulate the original message by omitting/including a section in which it made an appeal to the indifference and malevolence of

\footnotetext{
${ }^{1}$ Concearned about the potential dissemination of this rumor we asked participants to read a strong strong message designed by Mexico's police to stop the flow of violence-inducing rumors during the debriefing. See Appendix 3. The research design of this paper was submitted, reviewed and approved by Vanderbilt's IRB (No. 190684).
} 
government, by including a (mock) picture of the offenders, and by shifting the hypothetical source of the message.

As hypothesized, we find evidence that appeals to the untrustworthiness of government increase subjects' perception of the credibility and importance of violence-inducing rumors beyond other factors. Further, we find that these shifts increase individuals' willingness to disseminate these dangerous messages among their networks. Importantly, we find the effects of attitudes to go beyond information-sharing. Finally, we find individuals perceiving rumors as more credible, important, and sharable to be more likely to incite others to commit violence against alleged criminals when given a chance. The paper proceeds as follows. In the first section, we contextualize our study within the literature on the determinants of the spread of violence-inducing rumors. Then, we develop our main argument and introduce the methodology used to submit it to the test. Finally, we present our results and discuss their implications.

\section{The Dissemination of Rumors}

Lynchings infringe on the legal and human rights of alleged criminals, introduce social and political uncertainty and, when they are committed against innocent victims, constitute one of the most terrifying forms of popular injustice. Unsurprisingly, from the plains of Montana to the Bolivian Altiplano, the phenomenon attracted the attention of social scientists across the world (Allen 2004; Christian 2017; Goldstein 2004). However, a recent wave of collective violence organized through social networks (mainly WhatsApp) has rekindled journalistic and academic attention.

In India, a rumor claiming that a band of over 400 organ traffickers had infiltrated the city of Bangalore led to the lynching of an innocent 26 years-old immigrant walking through the street. In the impoverished neighborhood of Ciudad Bolivar (Bogotá), Colombia, a false rumor circulating in WhatsApp about the alleged abduction of a child lead led 150 citizens to beat to death a man misidentified as a kidnapper (Miranda 2018). And, in Argentina, a WhatsApp rumor about the 
purported rape of an innocent boy led an angry mob to lynch the father of a young man falsely accused of committing the crime (Peregil 2014). What factors contribute to the propagation of these dangerous rumors?

Determinants of the dissemination of rumors can be organized in individual and contextual forces. While the first relates to the political and social conditions that fuel the creation and distribution of rumors, the second connects to the forces that lead individuals to believe and propagate misinformation. Within the first group, the economy, for example, has been hypothesized to be connected with the distribution of rumors and the emergence of collective violence. Economic downturns are said to increase social frustration and group competition and, in doing so, increase the incentives for dominant elites to create rumors that allow them to escape accountability, reduce competition, and recover social order (Handy 2004; Hovland and Sears 1940; Oster 2004). Oster (2004), for example, found a direct relationship between the economic downturns that hit renaissance Europe and the prevalence of rumors of witchcraft across the continent. And, Hovland \& Sears (1940), as well as others since them (Christian 2017; Hepworth and West 1988; Tolnay and Beck 1995), have found an association between decreases in the price of cotton and the number of African Americans lynched after being accused of outrageous crimes through rumors (Senechal de la Roche 2001).

Objective conditions, however, are not necessary for the creation of violence-inducing rumors. Even in the absence of a negative economic environment, intense electoral and political competition can foster the conditions in which the kind of rumors that increase collective violence can emerge (Bagozzi 1977; Farooq 2018). In contexts of high electoral competition, parties face incentives to create WhatsApp groups to mobilize voters (Cheeseman et al. 2020; Farooq 2018; Moura and Michelson 2017) and to circulate outrageous information through them to benefit from the emotional effects that polarization can generate (Evangelista and Bruno 2019; Farooq 2018; Iyengar and Massey 
2019; Marcus, Neuman, and MacKuen 2000). To the extent that this information can include violenceinducing rumors, electoral polarization can lead to dreadful acts of collective violence (Ward 2020).

Interestingly, however, political polarization does not seem to be a necessary pre-condition for the circulation of violence-inducing rumors either. Bhavnani, Findley, and Kuklinski (2009), for example, developed an Agent-Based Model in which leaders interact with followers who disseminate rumors when they fall within a reasonable distance of their preconceptions. Over thousands of replications, they found that violence-inducing rumors can spread even in populations without strong leaders as long as individuals have a strong pre-existent belief in them and that, although leaders can play a role in rumor transmission, rumors frequently fail to disseminate in contexts in which individuals are not initially in tune with the ideas of the elites. Thus, just as the dangerousness of a virus is a function of its capacity to sicken hosts while allowing them to infect others, the dangerousness of violence-inducing rumors depends on their capacity to persuade individuals that they are accurate and shareable (Arun 2019; Phartiyal, Patnaik, and Ingram 2018).

Aware of this, a third strand of the literature has investigated the subpopulations that are more likely to believe and share misinformation. Age and gender, for instance, have been found to be connected with the acceptance and spread of misinformation (Chen et al. 2015; Guess, Nagler, and Tucker 2019; Halpern et al. 2019), and subjects with different personality traits have been found to be differently likely to disseminate rumors (Bronstein et al. 2019; Chen and Sin 2013; Lai et al. 2020; Wolverton and Stevens 2019). ${ }^{2}$ In general, correlational studies have found individuals scoring higher in extroversion (Chen and Sin 2013), non-agreeableness (Buchanan and Benson 2019), and openness to experience (Wolverton and Stevens 2019) have been found to be associated with individuals

\footnotetext{
2 While

Chen et al. (2015) as well as Halpern et al. (2019) find evidence that women are more likely to disseminate rumors. However, others have found the relation to go away under deeper scrutiny (Guess, Nagler, and Tucker 2019; Wolverton and Stevens 2019).
} 
willingness to accept and disseminate misinformation (Lai et al. 2020; Wolverton and Stevens 2019). Further, traits like fundamentalism, dogmatism (Bronstein et al. 2019), and bullshit receptivity (Pennycook and Rand 2020) have also been associated with individuals' willingness to disseminate rumors. Nevertheless, while identifying the subpopulations most likely to introject misinformation, the creation of effective interventions requires us to understand the states and behaviors that lead individuals to accept fake news, rumors, and other forms of misinformation.

Understanding this point, several studies have investigated the motivational, cognitive, and emotional forces that can increase citizens' willingness to accept rumors. Roozenbeek \& van der Linden (2019), for example, used a game to train individuals to identify the different strategies used to create misinformation and found citizens to become less likely to believe and spread fake news after becoming familiarized with this process even when accounting for their demographic, ideological, and cognitive characteristics. Pennycook et al. (2020), for their part, primed individuals to make more accurate evaluations through an implicit task and found individuals motivated in this way were more likely to believe and share false news and rumors about COVID-19. In addition to cognitive and motivational forces, emotional states have also been found to shape individuals' willingness to accept and share misinformation. Anxiety-inducing rumors, for instance, have been found to spread more rapidly than their relatively innocuous counterparts (DiFonzo and Bordia 2002; Pezzo and Beckstead 2006; Rosnow 1980; Walker and Beckerle 1987), and messages that include outraging misinformation have been found to be better able to persuade individuals to share them (Chuai and Zhao 2020; Coviello et al. 2014; Fan et al. 2014; Stieglitz and Dang-Xuan 2013). This is consistent with classic research arguing individuals to be less critical of new information (Huddy, Feldman, and Cassese 2007; Marcus, Neuman, and MacKuen 2000), to underestimate the risk (Lerner and Keltner 2001), and to seek-out aggressive information (Coan et al. 2020). 
All things considered, a growing number of scholars has studied the population dynamics of misinformation, focusing on the contextual, demographic, and individual forces that allow rumors to disseminate. Yet, as Bhavnani, Findley, Kuklinski (2009) show, understanding these contextual forces is not sufficient to comprehend the origins of violence-inducing rumors. Just as it is important to understand the anatomy and physiology of virus in order to produce vaccines and medication, it is critical to investigate how the information contained within rumors allows them to propagate in order to design effective strategies to fight their dissemination.

Because individuals tend to use heuristic and motivated reasoning (Lupia 1994; Taber and Lodge 2006), several authors have shown that rumors are better able to propagate when they include information that allows individuals to make rapid and facile judgments. For instance, when rumors contain endorsements by members of readers' political ingroup, they trigger an ingroup/outgroup mentality (Tajfel and Turner 1986), facilitate individual intake, and prevent corrections and rebuttals (Berinsky 2017; Nyhan and Reifler 2010). Further, because individuals are better able to process information when they have encountered it before, messages that contain familiar or redundant information tend to be more likely to persuade individuals of their credibility and importance (Berinsky 2017; Effron and Raj 2020; Greenhill and Oppenheim 2017; Pennycook, Cannon, and Rand 2018; Pennycook and Rand 2020). Pennycook, Cannon, Rand (2018), for instance, evaluated citizens' willingness to believe the fake news that circulated in the 2016 presidential election and found messages to be more credible when they contained misinformation to which individuals had been experimentally exposed previously. Berinsky (2017), for his part, showed that this familiarity effect remains strong even previous exposure comes from refutations, and Effron and Raj (2020) showed that citizens find more ethical to share blatantly false rumors when they have seen then repeated more frequently. Finally, under low information conditions, messages seeking to spread rumors are more effective in persuading individuals when they contain an endorsement from family and friends 
(Buchanan and Benson 2019; Hsu and Liang 2007). In their work on Whatsapp lynching in India, for example, Banaji et al. (2019) conducted qualitative interviews with individuals belonging to WhatsApp groups and found individuals, specially poorer and older, to be more likely to share violence-inducing rumors uncritically when they come from family members or close friends. Similarly, in a recent experimental study, Buchanan and Benson (2019) varied the hypothetical source of messages and found subjects to be more likely to share, like, comment, and react to Facebook posts disseminating misinformation when these posts were said to come from "a close family member" rather than an "unknown source".

In addition to these factors, in this paper, we argue that those seeking to disseminate and profit from misinformation often accompany their messages with subtle, and not so subtle, appeals to the untrustworthiness of government. These appeals, we argue, are a key part of the anatomy of misinformation and play a central role in the capacity of violence-inducing rumors to propagate

\section{Appeals to Government Distrust and The Spread of Rumors}

Long before the popularization of social networks, individuals seeking to propagate outlandish ideas and rumors have done so by appealing to what some have informally called the "Galileo Gambit" (Finocchiaro 2015; Johnson 2018). Broadly construed, this strategy consists of claiming that an idea or event is true because it reflects negatively on the reputation of the establishment and, therefore, generates incentives for rebuttals and attacks (Finocchiaro 2015). While it is true that the establishment has opposed numerous ideas, what makes this strategy fallacious is that it seeks to support the truth of a claim by triggering the audience's general distrust of those holding power rather than on logic or evidence.

Still, regardless of its epistemological dishonesty, this strategy has been shown to be quite effective. Long before the popularization of social media, proponents of the most outlandish conspiracy theories, as well as advocates of Supplementary, Complementary, and Alternative Medicine 
(SCAM) have used this strategy to promote their products through rumors (Finocchiaro 2015; Johnson 2018). Throughout the nineteen and twentieth centuries, for example, charlatans spread rumors of fraudulent cures for tuberculosis, cancer, and other ailments through rumors that contained appeals to the untrustworthy of the medical establishment (Newsom 2002) and, recently, the American author and fraudster Kevin Trudeau made millions marketing books that - like his famous "Natural Cures “They" Don't Want You to Know" - directly appealed to the public's distrust in the establishment. While Trudeau was ultimately sentenced to prison for fraud, his books made it to the top of the bestseller lists (Wisniewski 2014). ${ }^{3}$ The rise of social networks has only exacerbated the capacity of misinformation using anti-government appeals to disseminate. Every day, hundreds of thousands of messages circulating over social networks claiming vaccines to be toxic, promoting a novel cure for COVID-19 or CANCER, or denying the existence of HIV (Hern 2020).

We argue that appeals of this kind are not unique of health, political, and paranormal conspiracy rumors but also constitute a central strategy followed by those seeking to circulate crime rumors. In Europe, the United States, and India, false rumors about alleged crimes committed by immigrants have circulated within anti-immigrant groups accompanied by appeals to the indifference, incompetence, or complacency of the local or national authorities (Bohlken and Sergenti 2010; Horn 2016) and, in Latin America and Southeast Asia, the rumors about outrageous crimes that circulate in WhatsApp groups formed by neighborhood organizations, are frequently supplemented with complaints about the impunity prevailing in the country and the incompetence of law enforcement authorities (Banaji et al. 2019; Martínez-Cantera 2018; Zerega 2019).

Appeals to the indifference and incompetence of law enforcement authorities may exert their effects on the credibility and shareability of rumors through several mechanisms. First, these appeals

\footnotetext{
${ }^{3}$ Trudeau was ultimately sentenced to prison but his books More Natural Cures Revealed: Previously Censored Brand Name Products That Cure Disease, The Weight-Loss Cure "They" Don't Want You to Know About, and Debt Cures "They" Don't Want You to Know About made millins in revenue.
} 
can prime a general tendency to believe in conspiracies among a subsection of the population and, in doing so, increase their overall credibility. Citizens general tendency to believe in conspiracy theories has been found to play a critical role in their willingness to adopt fringe, unscientific, and even contradictory beliefs (Bruder et al. 2013; Imhoff et al. 2017; Landrum and Olshansky 2019; Moscovici 1987; Radnitz and Underwood 2017; Wood, Douglas, and Sutton 2012). Halpern et al. (2019), for instance, recently conducted a study in which they measured citizens' conspiracy mindset among a panel of Chileneans and found that individuals' disposition to believe in conspiracy theories is positively associated with their willingness to share fake news. Similarly, Landrum and Olshansky (2019) examined the correlates of citizens' willingness to accept scientific misinformation and found individuals scoring higher in a conspiracy mentality to be, both, more likely to deny well-established science and perceive as true inaccurate claims about GMOs, cancer, the Zika virus, and vaccinations. While we are unaware of studies linking a conspiracy mentality to citizens' acceptance of violenceinducing rumors, previous studies have found citizens prone to believe in conspiracies to be more likely to endorse violence (Imhoff, Dieterle, and Lamberty 2020; Jolley and Paterson 2020) and to be less like to endorse reconciliation in post-conflict societies (Petrović et al. 2019).

Second, appeals to the indifference and malevolence of government may decrease citizens' trust in authorities and, through a reverse likeability heuristic (Sniderman, Brody, and Tetlock 1993), citizens may impute their distrust in authorities into their assessment of the veracity of rumors. Vinck et al. (2019), for example, evaluated the impact of citizens' exposure to rumors on their willingness to engage in protective behavior (avoid direct contact, seek care, and vaccinate) during the Ebola virus outbreak in the Democratic Republic of Congo. Not only did they find an association between citizens' distrust in government and their exposure and belief in rumors, but they also found citizens holding lower levels of trust in authorities and health providers to be less likely to engage in protective behavior. For their part, Greenhill and Oppenheimer (2017) conducted face-to-face surveys with 
thousands of individuals in insurgency-affected areas of Thailand and the Philippines. They found citizens more distrusting in authorities to be more likely to evaluate false economic and security rumors as true. Moreover, they found citizens believing in rumors to be less likely to believe that conflict can be resolved, suggesting that shifts in citizens' trust in authorities not only contributes to the dissemination of rumors but also hinders the resolution of preexisting conflict.

Finally, appeals to the indifference of government can directly increase citizens’ preference for extralegal violence and, through a motivated reasoning mechanism, increase their likelihood to believe and share rumors that encourage citizens to engage in this type of behavior. Several studies have found evidence for the capacity of distrust in authorities. Seligson (2003) found general distrust in democracy to be linked with citizens' preference for extralegal justice, Malone (2012), as well as Hinton et al. (2014), found Latin-Americans more distrusting of the police to be more supportive of citizens taking the law into their own hands, and in a recent analysis of public opinion across the Americas, Cruz and Koppe-Santamaria (2019) found individuals holding a more negative view of the authorities to be more likely to agree with citizens exerting extralegal violence against alleged criminals. Similarly, Zizumbo-Colunga (2017) conducted an experimental study in Mexico and found that priming citizens to see authorities as untrustworthy increases their perception of collective extralegal criminal action as desirable. When coupling this evidence with the literature demonstrating that individuals are more likely to believe and share rumors that endorse actions with which they already agree (Allport and Lepkin 1945; Bordia and DiFonzo 2017; Rosnow 1991), it becomes clear that appeals to government distrust should increase citizens evaluation of the credibility of violence-inducing rumors.

In sum, appeals to citizens' distrust in elite and government actors have accompanied the discourse of those peddling pseudo-scientific medical, political, and technological ideas for decades. We note, however, that these appeals are not unique to the promotion of these ideas. In fact, those seeking to disseminate rumors about outrageous crimes often accompany their claims with appeals to 
the indifference, incompetence, and malevolence of law enforcement authorities. We have argued that, through several mechanisms, appeals of this kind help rumors persuade citizens about their credibility and importance and, in doing so, play a central role in the emergence of extralegal violence.

\section{Methods}

To test the aforementioned claim, we use data from an experiment included in the 2019 CIDEDATA open omnibus study. This is an open study coordinated by CIDEs' Social Science Experimentation Unit's (UECS-lab) to which students and academics from universities around the world can apply. The study consists of inviting students to participate in a laboratory study in which they engage with ten to fifteen short experimental studies (proposed by academics around the world). The study has the double purpose of introducing students to experimental laboratory research in social sciences and gathering data on the attitudes and political behavior of this subpopulation. All researchers participating in the UECS-DATA omnibus must commit to the international standards in the protection of human subjects, must have their projects reviewed by CIDE authorities, must have the authorization of their university's Institutional Review Board (IRB), or must submit their protocol to for the review of Vanderbilt University's IRB with the rest of the study.

Because of the low number of students at CIDE ( 200), UECS invites other universities to participate in the study to expand its sample. During the first stage of the study, UECS recruits professors teaching classes during the spring semester. Professors volunteering to participate in the study commit to allowing UECS to recruit student volunteers from their classes in exchange for extracredit. The week before the study, research assistants visit each class and invite students to register to visit the UECS-lab or one of the laboratories set up for the purposes of the study. The day of the study, each participant is welcomed into the laboratory, is registered in a participation sheet unlinked to the study's database, is directed to a computer station in the lab, and is allowed to answer the studies privately. To eliminate contamination across treatments, the order of the experiments selected to be 
included in the OMNIBUS -of which ours is only one - is randomized within participants. After finishing the study, students are debriefed and thanked for their participation. ${ }^{4}$ After the study, professors receive a list of all the students who visited the lab (regardless of whether they participated or not) and are reminded to assign extra credit students.

This round, a total of 968 participants visited one of the laboratories set by the UECS and completed the study. ${ }^{5} 10.9 \%$ of the subjects participated in the study at CIDE (an elite public university), and 7.24\% did so from two private universities (Universidad Cuauhtémoc Aguascalientes and Monterrey University). The rest of the participants (82\%) were recruited at the National Institute of Technology Campus Pabellón de Arteaga (TECNM-P), a small rural public university). Differences in the sub-sample size are likely to reflect differences in the size of the institutions, differential capacity by UECS' to recruit professors and differential interest by students. However, we see the bias in favor of TECNM-P to be a fortunate one for our study.

Located six hours north of Mexico City, thirty minutes north of the city of Aguascalientes, and an hour south of the city of Zacatecas, the geographic location of the TECNM-PA makes this university unique in that it attracts male and female students from impoverished rural localities across the region seeking to obtain a technical career. First, while they are in no way a representative sample of the population, students from this institution are likely to be more similar to the average citizen in developing countries than the students in elite institutions in Mexico and other countries. Second, in non-social science specializations, participants from TECNM-PA are less likely to be influenced by the normative education to which students recruited from psychology, law, or political science courses are. This provides us with a sample that is likely to react to outrageous rumors about crime in a way

\footnotetext{
${ }^{4}$ We were concearned that our study could introuduce negative rumors in the population. Thus, we exposed students to a very strong debrief designed by the law enforcement warning them of the falsehood of the rumor to which they were exposed. See Appendix 3.

${ }^{5}$ Less than $5 \%$ of participants rushed through the study to obtain the extra-credit. As described in the pre-registration protocol we removed these observations.
} 
more similar to the naïve WhatsApp user than students from classes designed to instill the democratic rule of law among pupils. Finally, although lynching occurs in both urban and rural areas (CastilloClaudett 2000; Goldstein 2004), it is important to note that the phenomenon has been most frequently observed in rural, traditional, and marginalized areas (Fuentes-Diaz 2004; Godoy 2006; Goldstein 2003; Mendoza 2009). Insofar and to the extent that students from TECNM-PA bring the voice of those living in the types of contexts in which collective violence is more likely to emerge, they may give us valuable insight on the psychology of those directly or indirectly participating in acts of selfserved justice.

The basic demographics of the sample were not radically different from a typical sample of this kind (Druckman and Kam 2011). In total, 45\% of those participating in the study were female, $75.75 \%$ were single, and the average participant's age was 24.10 (6.27) years old. What makes our sample unique was the socioeconomic profile of the average respondent. Participants' average monthly household income was about 13,523.2 Mexican pesos (about US $\$ 500$ at the time of the study), $61.97 \%$ of the students worked while they studied, and only a minority of them had a father $(25 \%)$ or a mother $(23 \%)$ that completed some form of professional education. With respect to their experiences with insecurity, the sample is not very different from the general population of Mexico (Cohen et al. 2017). 26.84\% of the respondents had been victimized by a crime in the 12 months before the study, $44.35 \%$ think that whenever a crime occurs in their community, the police is in collusion with criminals, and in a 0 to 100 scale, participants trust the police a 29.16.

\section{Study 1. Government Skepticism and Acceptance of Fake News}

To study the capacity of appealing to citizens' distrust in government to help violenceincentivizing rumors to propagate, we asked participants to react to a message sent by someone to a hypothetical Whatsapp group in which they participated. To increase the realism of the study, we used a section of a real message known to circulate in WhatsApp and known to be linked with a real case 
of collective violence. The message warns individuals about a supposed group of criminals stealing organs from adolescents and children, a very typical claim among violence-inciting rumors across the world (Banaji et al. 2019; Phartiyal, Patnaik, and Ingram 2018). Table 1 shows the message participants saw and its translation to English. While imperfect, this task allows us to directly observe individual behavior correlated with that displayed on a network that has remained impervious to researchers for years. Further, it allows us to constrain the capacity of citizens to disseminate dangerous misinformation among its networks and reduce the potential risks of the study. ${ }^{6}$

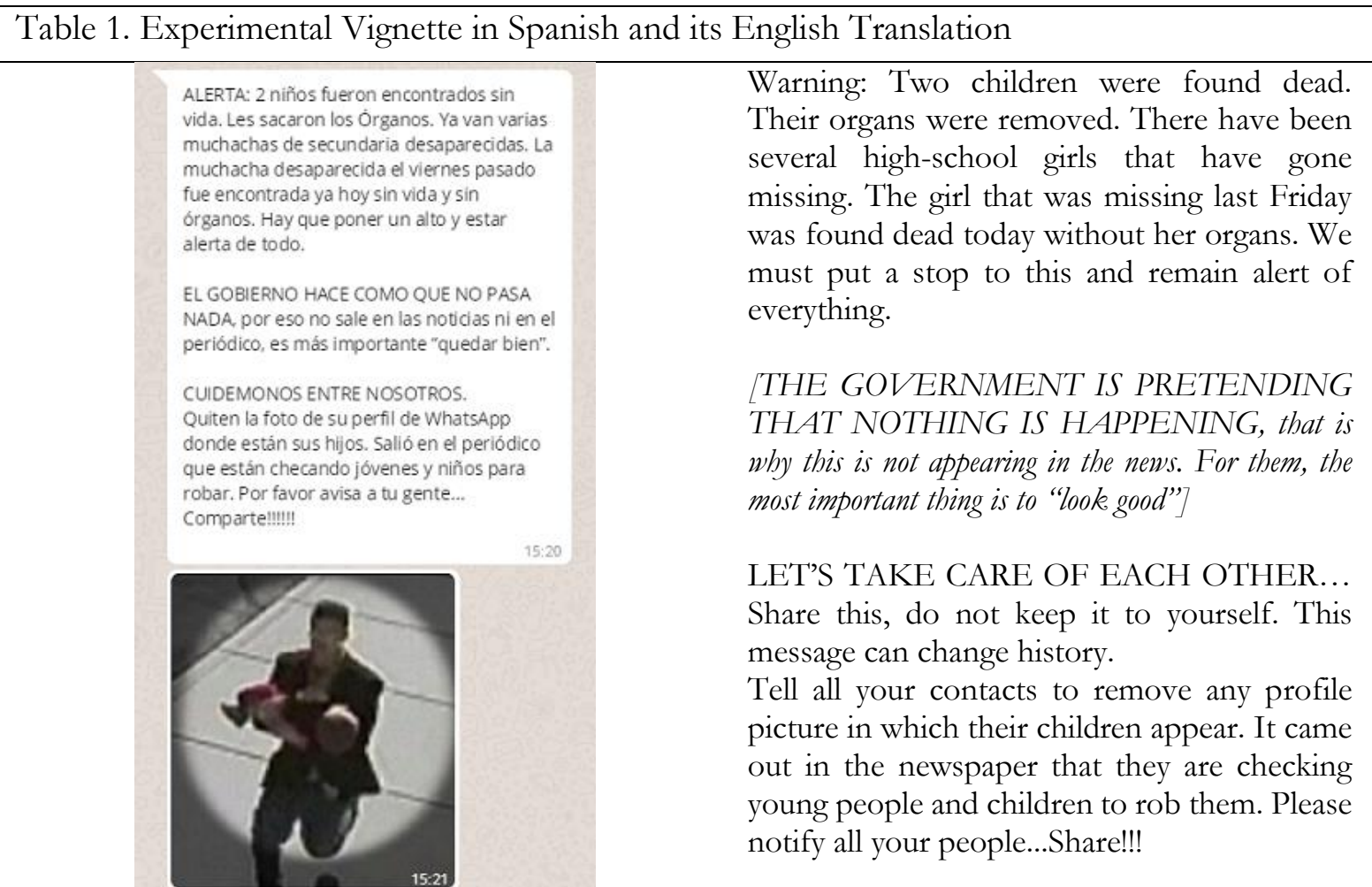

\footnotetext{
*The original message continues explaining how kidnappers use a drug called Axter to sleep and kidnap their victims. See Appendix 1 for the full message. We shortened the message to avoid tiring the participant.
}

Participants were given two options, to share or not to share the message. After making their decision, they were asked two questions designed to investigate the mechanisms by which the appeals studied exert their effects. We asked participants to report on a scale from 0 to 100 the extent to which

\footnotetext{
${ }^{6}$ As I will describe latter, participants were presented with a strong debriefing designed by law enforcement authorities after the study.
} 
they thought that sharing the information of the message was important and the extent to which they thought that the information contained in the message was true.

Overall, participants perceived the message as slightly untruthful (40.1) and very slightly unimportant (45). Still, nearly 51 percent of the participants indicated that they would share the message. To assess the impact of anti-government appeals relative to other features, we independently manipulated whether the message was sent by a familiar or an unfamiliar source (Remittent), whether the message included visual evidence of the crime (Picture), and whether the message included an appeal aimed at triggering respondents' distrust in government (Government). We hypothesize that information providing participants with visual evidence, cues that the message was shared by a familiar source, and appealing to citizens' distrust in government will increase the perceived credibility, importance, and shareability of rumors. To evaluate whether this is the case, we specified a series of OLS and logistic regression models in which individuals' perception of the message was modeled as a function of participants' demographic and attitudinal characteristics as well as the features of the message manipulated.

\section{Results}

Table 1 shows the first set of models that test whether the manipulations increased the credibility and perceived importance of the message. Columns 1 and 2 estimate the simple ATE of each manipulation and Columns 3 and 4 estimate these effects in conjunction with other potentially relevant variables for comparison. In both models, we included Institution and Order fixed effects to account for contextual and contagion effects across the treatments included in the omnibus study. 


\begin{tabular}{|c|c|c|c|c|}
\hline VARIABLES & $\begin{array}{c}\text { (1) } \\
\text { Credibility } \\
\end{array}$ & $\begin{array}{c}(2) \\
\text { Importance }\end{array}$ & $\begin{array}{c}\text { (3) } \\
\text { Credibility }\end{array}$ & $\begin{array}{c}(4) \\
\text { Importance }\end{array}$ \\
\hline Government & $\begin{array}{c}4.117 * * * \\
(1.562)\end{array}$ & $\begin{array}{l}3.000^{\wedge} \\
(2.128)\end{array}$ & $\begin{array}{c}4.320^{* * *} \\
(1.572)\end{array}$ & $\begin{array}{l}3.304^{\wedge} \\
(2.143)\end{array}$ \\
\hline Picture & $\begin{array}{c}0.638 \\
(1.566)\end{array}$ & $\begin{array}{l}1.768 \\
(2.135)\end{array}$ & $\begin{array}{c}0.748 \\
(1.575)\end{array}$ & $\begin{array}{c}1.730 \\
(2.148)\end{array}$ \\
\hline Source Familiarity & $\begin{array}{l}-1.825 \\
(1.670)\end{array}$ & $\begin{array}{l}-1.969 \\
(2.276)\end{array}$ & $\begin{array}{l}-1.441 \\
(1.682)\end{array}$ & $\begin{array}{l}-1.815 \\
(2.293)\end{array}$ \\
\hline Female & & & $\begin{array}{c}5.102^{* * *} \\
(1.631)\end{array}$ & $\begin{array}{l}3.623^{\wedge} \\
(2.224)\end{array}$ \\
\hline Age & & & $\begin{array}{c}-6.815^{\wedge} \\
(5.069)\end{array}$ & $\begin{array}{l}-2.209 \\
(6.911)\end{array}$ \\
\hline Household Income & & & $\begin{array}{l}-9.849 \\
(11.33)\end{array}$ & $\begin{array}{l}-24.22^{\wedge} \\
(15.45)\end{array}$ \\
\hline Father's Schooling & & & $\begin{array}{l}-6.281 \\
(5.058)\end{array}$ & $\begin{array}{c}-16.72^{* *} \\
(6.896)\end{array}$ \\
\hline Mother's Schooling & & & $\begin{array}{l}-2.067 \\
(5.439)\end{array}$ & $\begin{array}{c}2.912 \\
(7.416)\end{array}$ \\
\hline Crime Victimization & & & $\begin{array}{l}1.809 \\
(1.745)\end{array}$ & $\begin{array}{l}5.188^{* *} \\
(2.380)\end{array}$ \\
\hline Respect vs. Independence & & & $\begin{array}{l}3.717^{*} \\
(1.988)\end{array}$ & $\begin{array}{l}4.095^{\wedge} \\
(2.711)\end{array}$ \\
\hline Good Manners vs. Curiosity & & & $\begin{array}{c}0.589 \\
(2.375)\end{array}$ & $\begin{array}{l}-0.717 \\
(3.239)\end{array}$ \\
\hline Self-confidence vs. Obedience & & & $\begin{array}{c}-0.00447 \\
(0.855)\end{array}$ & $\begin{array}{l}0.0632 \\
(1.166)\end{array}$ \\
\hline Iron Fist leader & & & $\begin{array}{c}1.550 \\
(2.335)\end{array}$ & $\begin{array}{l}5.921 * \\
(3.184)\end{array}$ \\
\hline Left - Right & & & $\begin{array}{l}7.861 * * \\
(3.474)\end{array}$ & $\begin{array}{l}11.62^{* *} \\
(4.736)\end{array}$ \\
\hline Support - EPN & & & $\begin{array}{l}-5.987^{*} \\
(3.455)\end{array}$ & $\begin{array}{l}-5.893 \\
(4.711)\end{array}$ \\
\hline Support - AMLO & & & $\begin{array}{c}9.772^{* * *} \\
(2.768)\end{array}$ & $\begin{array}{c}13.75^{* * *} \\
(3.774)\end{array}$ \\
\hline $\begin{array}{l}\text { Order F.E. } \\
\text { Institution F.E. }\end{array}$ & $\begin{array}{l}\text { Yes } \\
\text { Yes }\end{array}$ & $\begin{array}{l}\text { Yes } \\
\text { Yes }\end{array}$ & $\begin{array}{l}\text { Yes } \\
\text { Yes }\end{array}$ & $\begin{array}{l}\text { Yes } \\
\text { Yes }\end{array}$ \\
\hline Constant & $\begin{array}{c}42.32^{* * *} \\
(5.787)\end{array}$ & $\begin{array}{c}34.28^{* * *} \\
(7.886)\end{array}$ & $\begin{array}{c}34.52^{* * *} \\
(8.481)\end{array}$ & $\begin{array}{l}19.32^{*} \\
(11.57)\end{array}$ \\
\hline $\begin{array}{l}\text { Observations } \\
\text { R-squared }\end{array}$ & $\begin{array}{c}965 \\
0.097\end{array}$ & $\begin{array}{c}965 \\
0.127\end{array}$ & $\begin{array}{c}921 \\
0.151\end{array}$ & $\begin{array}{c}921 \\
0.184\end{array}$ \\
\hline
\end{tabular}


As the table shows, we find females, those who think instilling respect in children is more important than instilling independence, more rightist individuals, and those more supportive of the incumbent president to perceive the message as more truthful. Furthermore, we find those coming from a household with a father with lower education, those more intensely victimized by crime, those thinking that the country needs a leader with an iron fist, those more right-leaning, and those more supportive of the incumbent to be more likely to perceive it to be important for them to share the information.

With respect to the experimental manipulations, we find that appeals to the untrustworthiness of government carry the strongest impact among all the treatments. In fact, when manipulated along with our treatment of interest, we find no evidence that the other manipulations influenced participants' perceptions of the rumor. Figure 1 show the effects of the manipulations on the perceived credibility and importance of the rumor. Hollow circles indicate statistically insignificant effects.

Figure 1. Effect of Manipulations on the Perceived Credibility and Importance of the Message

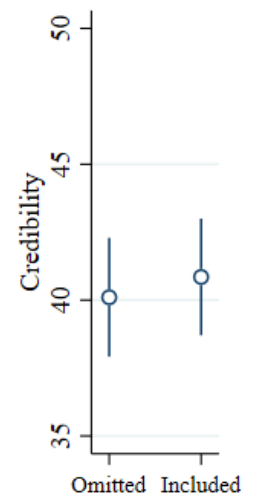

Picture

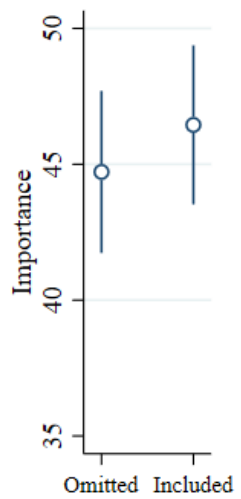

Picture

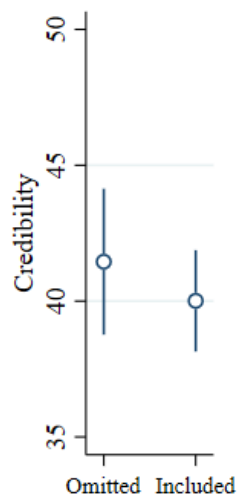

Familiar

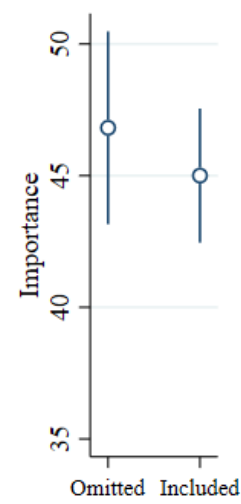

Familiar

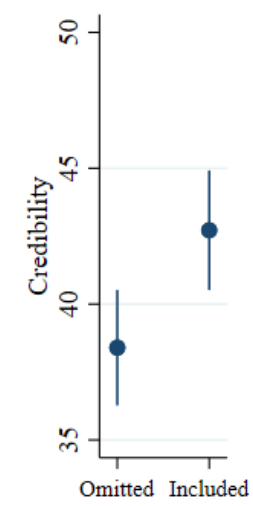

Government

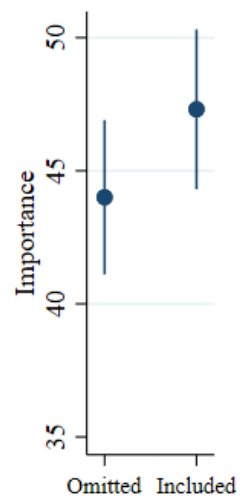

Government

Vertical lines represent 95\% confidence intervals. Hollow circles indicate non-significant differences.

As the rightmost figures show, including an anti-government appeal increases the perceived importance of the message by 4.3 percentage points. That is, it increases the participants' perception that sharing the information in the message is important from 43.98 to 47.32 . Similarly, this type of appeals increases the believability of this kind of WhatsApp rumors by 3.33 percentage points. On 
average, participants gave the message in which the anti-government appeal was omitted a 38.36 believability score and the regular message in which an anti-government score was included an average of 42.75 .

To evaluate the extent to which these evaluations translated into citizens' willingness to share the rumor, we estimated a second set of models. This time, we estimate a logistic regression model in which the probability of an individual to share the message is a function of the extent to which he/she finds it believable and important along with the pre-treatment controls included in the previous model. Column 1 and 2 display the total impact of each type of perception (Importance and Credibility), Column 3 shows their partial effect for each variable while the other is held constant, and Column 4 shows the downstream effect of the treatments on citizens' willingness to share the message. 


\begin{tabular}{|c|c|c|c|c|}
\hline VARIABLES & $\begin{array}{l}(1) \\
\text { Share }\end{array}$ & $\begin{array}{c}(2) \\
\text { Share }\end{array}$ & $\begin{array}{c}(3) \\
\text { Share }\end{array}$ & $\begin{array}{l}\text { (4) } \\
\text { Share }\end{array}$ \\
\hline Government & & & & $\begin{array}{l}0.200^{\wedge} \\
(0.152)\end{array}$ \\
\hline Image & & & & $\begin{array}{l}0.0910 \\
(0.152)\end{array}$ \\
\hline Remittent & & & & $\begin{array}{c}0.00886 \\
(0.161)\end{array}$ \\
\hline Credibility & $\begin{array}{c}6.768^{* * *} \\
(0.513)\end{array}$ & & $\begin{array}{c}3.395^{* * *} \\
(0.617)\end{array}$ & \\
\hline Importance & & $\begin{array}{c}7.776^{* * *} \\
(0.535)\end{array}$ & $\begin{array}{c}6.813 * * * \\
(0.555)\end{array}$ & \\
\hline Female & $\begin{array}{l}0.0499 \\
(0.189)\end{array}$ & $\begin{array}{l}0.0776 \\
(0.229)\end{array}$ & $\begin{array}{r}-0.0181 \\
(0.238)\end{array}$ & $\begin{array}{l}0.284^{*} \\
(0.159)\end{array}$ \\
\hline Age & $\begin{array}{l}0.852^{\wedge} \\
(0.626)\end{array}$ & $\begin{array}{c}0.637 \\
(0.728)\end{array}$ & $\begin{array}{l}1.112^{\wedge} \\
(0.784)\end{array}$ & $\begin{array}{l}0.0602 \\
(0.485)\end{array}$ \\
\hline Home wealth & $\begin{array}{l}-2.243 \\
(1.919)\end{array}$ & $\begin{array}{l}-0.815 \\
(2.390)\end{array}$ & $\begin{array}{l}-0.552 \\
(2.383)\end{array}$ & $\begin{array}{c}-2.848^{\wedge} \\
(1.799)\end{array}$ \\
\hline Father's Schooling & $\begin{array}{c}-1.077^{*} \\
(0.605)\end{array}$ & $\begin{array}{l}-0.481 \\
(0.743)\end{array}$ & $\begin{array}{l}-0.590 \\
(0.787)\end{array}$ & $\begin{array}{c}-1.148^{* *} \\
(0.499)\end{array}$ \\
\hline Mother's Schooling & $\begin{array}{l}1.259^{*} \\
(0.671)\end{array}$ & $\begin{array}{l}1.126^{\wedge} \\
(0.806)\end{array}$ & $\begin{array}{l}1.246^{\wedge} \\
(0.851)\end{array}$ & $\begin{array}{l}0.832^{\wedge} \\
(0.554)\end{array}$ \\
\hline Crime Victimization & $\begin{array}{l}0.331^{*} \\
(0.197)\end{array}$ & $\begin{array}{c}0.109 \\
(0.239)\end{array}$ & $\begin{array}{c}0.152 \\
(0.249)\end{array}$ & $\begin{array}{c}0.341 * * \\
(0.163)\end{array}$ \\
\hline Respect vs Independence & $\begin{array}{c}0.661^{* * *} * \\
(0.224)\end{array}$ & $\begin{array}{c}0.961^{* * *} \\
(0.278)\end{array}$ & $\begin{array}{c}0.883^{* * *} * \\
(0.288)\end{array}$ & $\begin{array}{c}0.687^{* * *} \\
(0.185)\end{array}$ \\
\hline Good Manners vs Curiosity & $\begin{array}{l}-0.357 \\
(0.282)\end{array}$ & $\begin{array}{l}-0.419 \\
(0.340)\end{array}$ & $\begin{array}{c}-0.492^{\wedge} \\
(0.361)\end{array}$ & $\begin{array}{l}-0.204 \\
(0.231)\end{array}$ \\
\hline Self-confidence vs Obedience & $\begin{array}{c}-0.0211 \\
(0.102)\end{array}$ & $\begin{array}{c}-0.0396 \\
(0.120)\end{array}$ & $\begin{array}{c}-0.0582 \\
(0.122)\end{array}$ & $\begin{array}{c}-0.000664 \\
(0.0867)\end{array}$ \\
\hline Iron Fist leader & $\begin{array}{l}-0.231 \\
(0.278)\end{array}$ & $\begin{array}{c}-0.965^{* * *} \\
(0.353)\end{array}$ & $\begin{array}{c}-1.058^{* * *} \\
(0.370)\end{array}$ & $\begin{array}{c}-0.0836 \\
(0.228)\end{array}$ \\
\hline Left - Right & $\begin{array}{c}0.494 \\
(0.418)\end{array}$ & $\begin{array}{c}0.647 \\
(0.510)\end{array}$ & $\begin{array}{l}0.682^{\wedge} \\
(0.529)\end{array}$ & $\begin{array}{l}0.648^{*} \\
(0.337)\end{array}$ \\
\hline Support - EPN & $\begin{array}{l}-0.469 \\
(0.416)\end{array}$ & $\begin{array}{c}-0.685^{\wedge} \\
(0.497)\end{array}$ & $\begin{array}{c}-0.692^{\wedge} \\
(0.516)\end{array}$ & $\begin{array}{c}-0.550^{*} \\
(0.330)\end{array}$ \\
\hline Support - AMLO & $\begin{array}{c}0.289 \\
(0.323)\end{array}$ & $\begin{array}{l}0.0805 \\
(0.395)\end{array}$ & $\begin{array}{l}-0.126 \\
(0.406)\end{array}$ & $\begin{array}{c}0.688^{* * *} \\
(0.265)\end{array}$ \\
\hline Constant & $\begin{array}{c}-4.377^{* * *} * \\
(0.868)\end{array}$ & $\begin{array}{c}-4.635^{* * *} \\
(1.063)\end{array}$ & $\begin{array}{c}-5.475^{* * *} \\
(1.110)\end{array}$ & $\begin{array}{c}-1.698^{* *} \\
(0.733)\end{array}$ \\
\hline Observations & 921 & 921 & 921 & 921 \\
\hline
\end{tabular}

As the table shows, we found that individuals who see the message as more credible and more important are also more likely to share it. Figures 7 and 8 show the close association between participants' evaluations and their willingness to share the message. Figure 9 shows the downstream 
effect of appealing to citizens' distrust in government on participants' willingness to share the WhatsApp message presented in the study.

Figure 2. Message Evaluations and Dispositions to Share

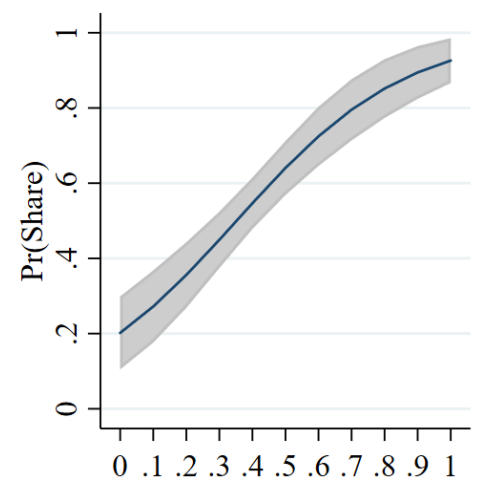

Credibility

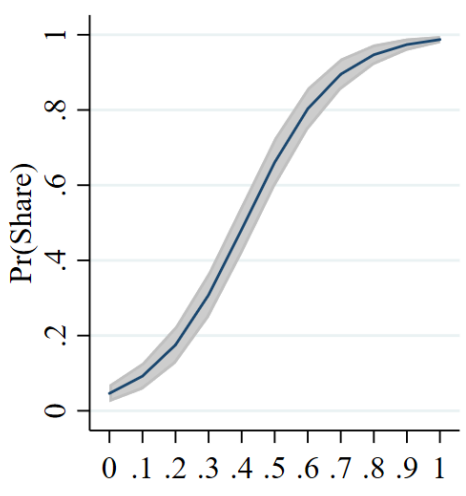

Importance

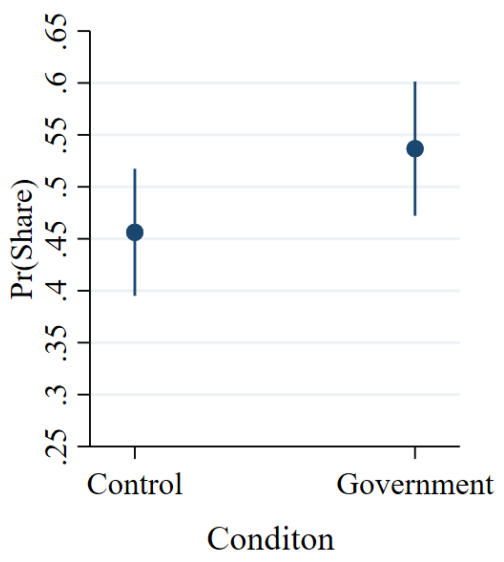

Grey Areas and Vertical Line Display 95\% Confidence Intervals

Holding other things constant (including the perceived importance of the message), changing the average participant's perception from one standard deviation below the mean (0.25) to one standard deviation above the mean (0.65) increases his/her disposition to share the message from $47.8 \%$ to $78.1 \%$. Changing participants' perceptions of the importance of the message, in the same way, increases their disposition to share the message by fifty percentage points, taking it from $35 \%$ to 85\%. Given this close association, we find the downstream effect of the anti-government appeal to be evident even with this relatively small number of observations. Holding other things constant but changing the contents of the rumor to include an anti-government appeal increases the proportion of individuals sharing the message from $50.7 \%$ to $55.7 \%$. This represents a 9.86 percent growth in the proportion of individuals sharing the message.

\section{Study 2. The Consequences of Rumor Intake on Violence}

The dangerous nature of this message, as well as the exponential nature of the spread of rumors, make the findings presented so far important. However, it is crucial to consider that sharing 
and endorsing dangerous messages as the one presented to participants in this study is only one part of the complex phenomenon of deadly violence. For a lynching to occur, someone in the community must water the seed of violence sown by messages of this kind. To evaluate the extent to which varying citizens' evaluations of the truthfulness, importance, and shareability of this kind of rumors impact their willingness to play an active role in sparking the flame of violence when given a chance, we created a secondary task.

In this task, we asked participants to imagine that, shortly after receiving the initial message, a group of neighbors sent a follow up saying: "We caught some scoundrels wandering around in front of the school. They were the ones mentioned on WhatsApp" implying that a group of neighbors detained a group of suspicious men and are accusing them of being the ones involved in organ trafficking. We asked participants to choose the response that would best represent their likely answer from five possible responses (Figure 10).

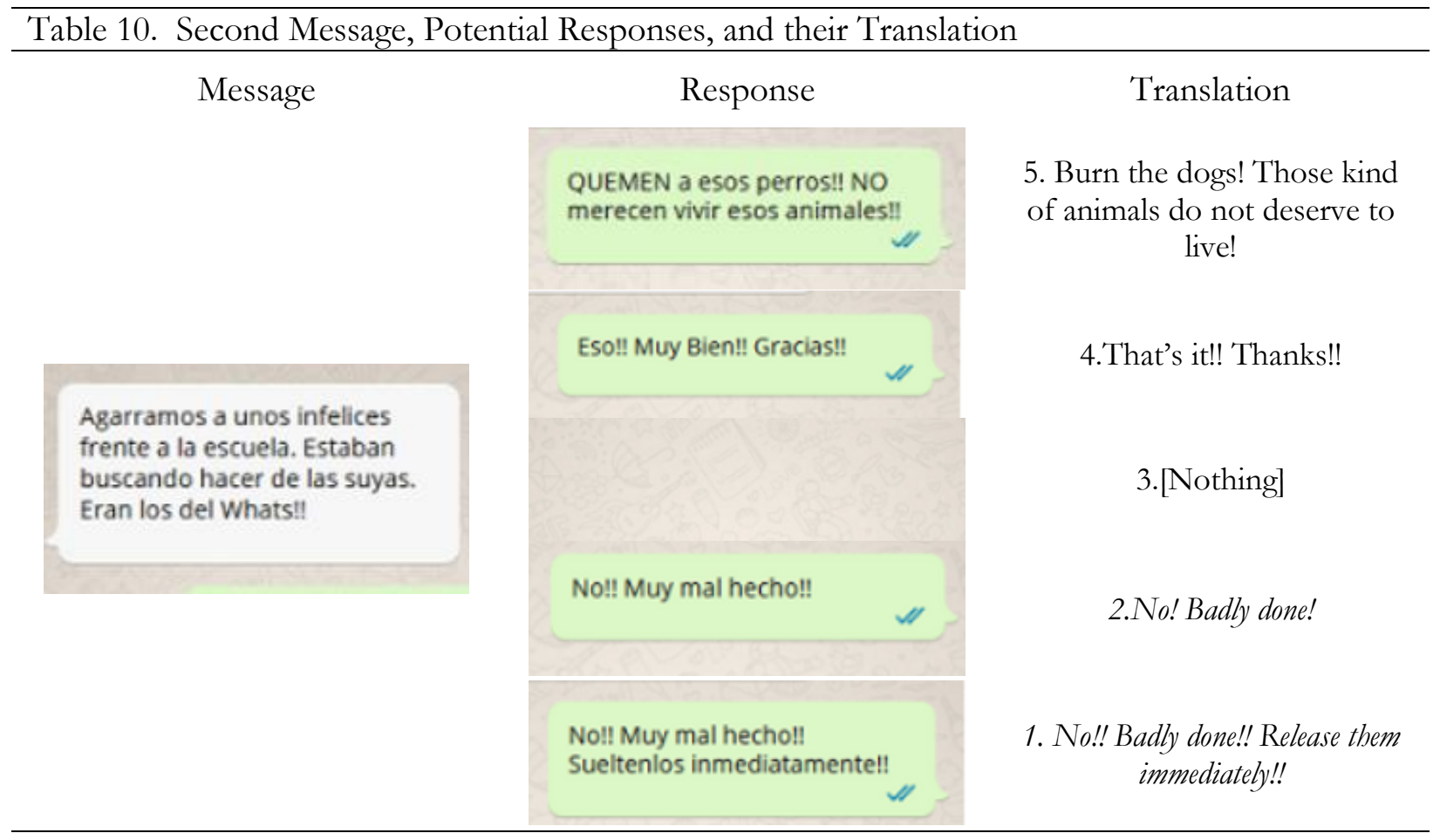


Two responses (4 and 5) were designed to express support for the extralegal violence, two responses were designed to convey opposition to extralegal violence (1 and 2), and one was designed to express apathy/neutrality (3). Within the opposition responses, one involved condemning vigilante action (2) and one involved attempting to stop extralegal justice (1). Within the supportive responses, one involved endorsing extralegal action (4), and the other involved dehumanizing the suspected criminals and encouraging others to engage in extralegal violence (5). These potential responses were chosen because they reflect a single dimension going from opposition to support for extralegal violence but also because they reflect the type of violence that individuals endorse when they respond to violence-inducing rumors (see Appendix 2 for an example).

We find that $42.5 \%$ of participants remained neutral to the message. However, to our surprise, participants were not shy to manifest their support for violence. In fact, only $6.63 \%$ some sort of condemnation or opposition the neighbor's action and 50.88\% of the participants manifested positive attitudes towards vigilante action. In total, $38 \%$ of the participants congratulated the neighbors for their initiative and $12.33 \%$ of those participating in the study encouraged the senders of the message to burn the detainees alive.

To assess the degree to which participants' evaluation of the rumor affected their willingness to incite others to commit violence, we specified a series of ordered logistic regression models in which the level of violence endorsed by participants is modeled as a function of subjects' assessment of the rumor to which they were exposed seconds before. Columns 1 through 3 display the total effect of each of the measured evaluations on violence-incitement. Column 4 displays the partial effect of each evaluation on citizens' reactions. ${ }^{7}$ In the last model (Column 4 ) we included the experimental

\footnotetext{
${ }^{7}$ By "the partial effect of the treatments" we mean the effect of each manipulation net of its impact on individuals' willingness to believe the message to be truthful and important. Null effects here do not necessarily reflect a lack of evidence for the effect of $\mathrm{X}$ on $\mathrm{Y}$, they may reflect a lack of evidence for the effect of $\mathrm{X}$ on $\mathrm{Y}$ outside of its effects on mediating variables $\mathrm{M}$, in this case, rumor evaluation.
} 
manipulations to measure whether they influenced citizens' willingness to incite others to commit violence independently of their effects on the intake of violence-inducing rumors.

\begin{tabular}{|c|c|c|c|c|}
\hline & $\begin{array}{c}(1) \\
\text { Violence }\end{array}$ & $\begin{array}{c}(2) \\
\text { Violence }\end{array}$ & $\begin{array}{c}(3) \\
\text { Violence }\end{array}$ & $\begin{array}{c}(4) \\
\text { Violence }\end{array}$ \\
\hline Credibility & $\begin{array}{c}1.922^{* * *} \\
(0.281)\end{array}$ & & & $\begin{array}{c}0.750^{* *} \\
(0.359)\end{array}$ \\
\hline Importance & & $\begin{array}{c}1.698^{* * *} \\
(0.209)\end{array}$ & & $\begin{array}{c}1.103^{* * *} \\
(0.313)\end{array}$ \\
\hline Shared the Rumor & & & $\begin{array}{c}0.986^{* * *} \\
(0.146)\end{array}$ & $\begin{array}{l}0.278^{\wedge} \\
(0.202)\end{array}$ \\
\hline Government & & & & $\begin{array}{c}-0.0275 \\
(0.130)\end{array}$ \\
\hline Offender's Picture & & & & $\begin{array}{c}-0.380^{* * * *} \\
(0.130)\end{array}$ \\
\hline Source Familiarity & & & & $\begin{array}{r}-0.0753 \\
(0.0786)\end{array}$ \\
\hline Female & $\begin{array}{c}-0.634 * * * \\
(0.135)\end{array}$ & $\begin{array}{c}-0.602^{* * *} \\
(0.135)\end{array}$ & $\begin{array}{c}-0.583 * * * \\
(0.135)\end{array}$ & $\begin{array}{c}-0.635 * * * \\
(0.136)\end{array}$ \\
\hline Age & $\begin{array}{l}-0.407 \\
(0.405)\end{array}$ & $\begin{array}{l}-0.448 \\
(0.405)\end{array}$ & $\begin{array}{c}-0.530^{\wedge} \\
(0.405)\end{array}$ & $\begin{array}{l}-0.383 \\
(0.408)\end{array}$ \\
\hline Home wealth & $\begin{array}{l}-0.657 \\
(0.592)\end{array}$ & $\begin{array}{c}-0.918^{\wedge} \\
(0.595)\end{array}$ & $\begin{array}{c}-0.840^{\wedge} \\
(0.594)\end{array}$ & $\begin{array}{c}-0.955^{\wedge} \\
(0.598)\end{array}$ \\
\hline Father's Schooling & $\begin{array}{c}-0.817^{*} \\
(0.419)\end{array}$ & $\begin{array}{c}-0.722^{*} \\
(0.418)\end{array}$ & $\begin{array}{c}-0.765^{*} \\
(0.419)\end{array}$ & $\begin{array}{l}-0.654^{\wedge} \\
(0.421)\end{array}$ \\
\hline Mother's Schooling & $\begin{array}{c}0.125 \\
(0.445)\end{array}$ & $\begin{array}{l}0.0298 \\
(0.446)\end{array}$ & $\begin{array}{c}-0.0486 \\
(0.446)\end{array}$ & $\begin{array}{c}-0.0716 \\
(0.449)\end{array}$ \\
\hline Respect vs Independence & $\begin{array}{l}0.235^{\wedge} \\
(0.143)\end{array}$ & $\begin{array}{c}0.183 \\
(0.144)\end{array}$ & $\begin{array}{l}0.201^{\wedge} \\
(0.144)\end{array}$ & $\begin{array}{l}0.200^{\wedge} \\
(0.145)\end{array}$ \\
\hline Good Manners vs Curiosity & $\begin{array}{c}-0.0198 \\
(0.163)\end{array}$ & $\begin{array}{r}-0.0128 \\
(0.164)\end{array}$ & $\begin{array}{l}-0.100 \\
(0.164)\end{array}$ & $\begin{array}{c}-0.0456 \\
(0.166)\end{array}$ \\
\hline Self-confidence vs Obedience & $\begin{array}{c}-0.281^{\wedge} \\
(0.192)\end{array}$ & $\begin{array}{c}-0.249^{\wedge} \\
(0.193)\end{array}$ & $\begin{array}{l}-0.240 \\
(0.193)\end{array}$ & $\begin{array}{c}-0.249^{\wedge} \\
(0.194)\end{array}$ \\
\hline Crime Victimization & $\begin{array}{c}0.0541 \\
(0.0708)\end{array}$ & $\begin{array}{c}0.0481 \\
(0.0713)\end{array}$ & $\begin{array}{c}0.0611 \\
(0.0709)\end{array}$ & $\begin{array}{c}0.0507 \\
(0.0716)\end{array}$ \\
\hline Iron Fist leader & $\begin{array}{c}0.864 * * * \\
(0.194)\end{array}$ & $\begin{array}{c}0.806^{* * *} \\
(0.195)\end{array}$ & $\begin{array}{c}0.913 * * * \\
(0.194)\end{array}$ & $\begin{array}{c}0.872^{* * *} \\
(0.196)\end{array}$ \\
\hline Left-right & $\begin{array}{l}0.474^{*} \\
(0.287)\end{array}$ & $\begin{array}{l}0.419^{\wedge} \\
(0.286)\end{array}$ & $\begin{array}{l}0.485^{*} \\
(0.286)\end{array}$ & $\begin{array}{c}0.340 \\
(0.288)\end{array}$ \\
\hline Support for Peña Nieto & $\begin{array}{l}-0.248 \\
(0.283)\end{array}$ & $\begin{array}{l}-0.279 \\
(0.283)\end{array}$ & $\begin{array}{l}-0.213 \\
(0.283)\end{array}$ & $\begin{array}{l}-0.180 \\
(0.285)\end{array}$ \\
\hline Support for AMLO & $\begin{array}{c}0.198 \\
(0.229) \\
\end{array}$ & $\begin{array}{c}0.137 \\
(0.230) \\
\end{array}$ & $\begin{array}{c}0.251 \\
(0.229) \\
\end{array}$ & $\begin{array}{c}0.119 \\
(0.231) \\
\end{array}$ \\
\hline Order Fixed Effects & Yes & Yes & Yes & Yes \\
\hline Institution Fixed Effects & Yes & Yes & Yes & Yes \\
\hline Thresholds $(\tau 1-\tau 4)$ & Yes & Yes & Yes & Yes \\
\hline Observations & 921 & 921 & 921 & 921 \\
\hline R-squared & 0.207 & 0.192 & 0.214 & 0.196 \\
\hline
\end{tabular}


As the table shows, we find those seeing rumors as more credible, important, and shareable to also be more willing to incite others to commit violence. Interestingly, despite it having a null effect on citizens' evaluations of the credibility and importance of sharing rumors, we find that exposing individuals to images of the criminals mentioned in the rumors influence subjects' willingness to incite violence. The effect of images, however, runs contrary to our initial expectations. Rather than increasing citizens' disposition to instigate violence, they decrease it. This suggests that messages that do not include images might be more dangerous than messages that include them. ${ }^{8}$ The precise reason for this effect is unclear and merits further investigation. We find no evidence that appeals to government distrust influenced citizens' willingness to incite violence outside of their effects on subjects' evaluations. This, of course, does not mean that government appeals do not influence citizens' willingness to incite violence. It merely indicates that, in this study, their effect was fully mediated by message evaluations. Figures 1 through 4 display the substantive impact of the variables showing to have a significant effect on participants' willingness to give the most radical answer to the question, inciting neighbors to burn the detainees alive.

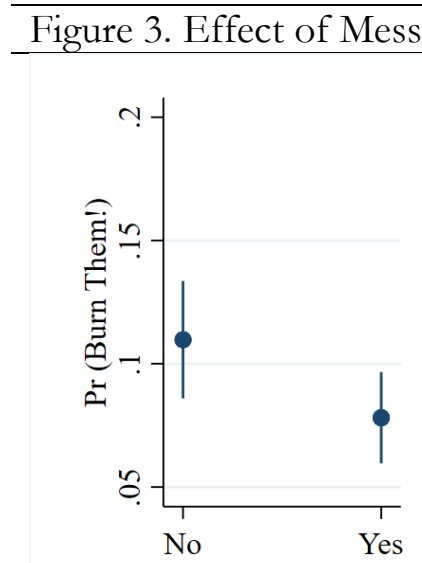

Picture Included

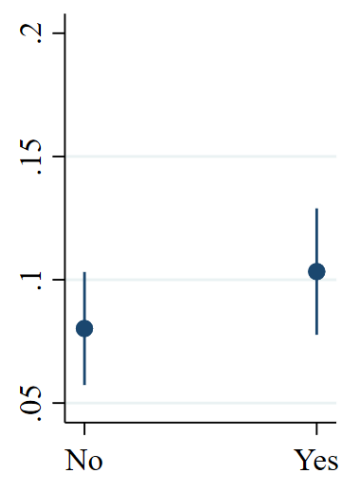

Shared the Message

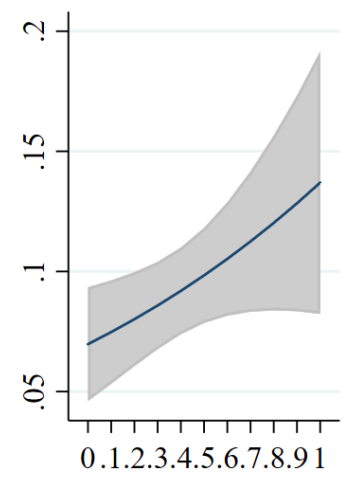

Truthfulness

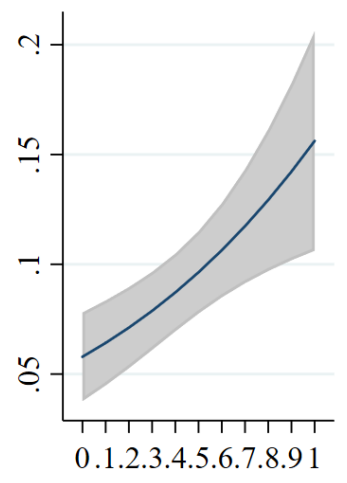

Importance

Grey Areas and Vertical Line Display 95\% Confidence Intervals

\footnotetext{
${ }^{8}$ The effect of visual images on individuals' disposition to instigate violence $(\beta-0.291, \mathrm{p}<0.05)$ is apparent even when
} omitting all control variables. 
While an average participant assigned to see a message without a picture has a $10.9 \%$ chance of inciting others to commit violence, a participant assigned to see a message with a picture has a $7.8 \%$ chance of doing so (Figure 11). Additionally, moving an average participant's perception of the credibility of the rumor from one standard deviation below the mean $(25 \%)$ to one standard deviation above the mean (65\%) increases his/her willingness to incite others to commit violence from $8.2 \%$ to $10.87 \%$. That is, it increases violence incitement by thirty-five percent. Similarly, increasing a participants' perception that it is important to share the information contained in the rumor in the same amount (from -1SD to +1SD), increases his/her willingness to incite violence from $6.4 \%$ to $12.8 \%$. That is, it doubles his/her propensity to incite others to engage in deadly violence. Finally, we find evidence that rumor-sharing has significant effects on dispositions. That is, even when accounting for an individuals' perception of the message, we find that persuading an average individual to share a rumor increases her subsequent likelihood to incite others to commit violence, by twenty-eight percent (increasing it from $8 \%$ to $10.3 \%$ ).

To summarize the general structure of the effects found in this study, we present a path diagram displaying both the direct and indirect treatment effects of the manipulates. Estimates control for pre-treatment covariates as well as order and university fixed effects. We omit control and insignificant paths for simplicity. 


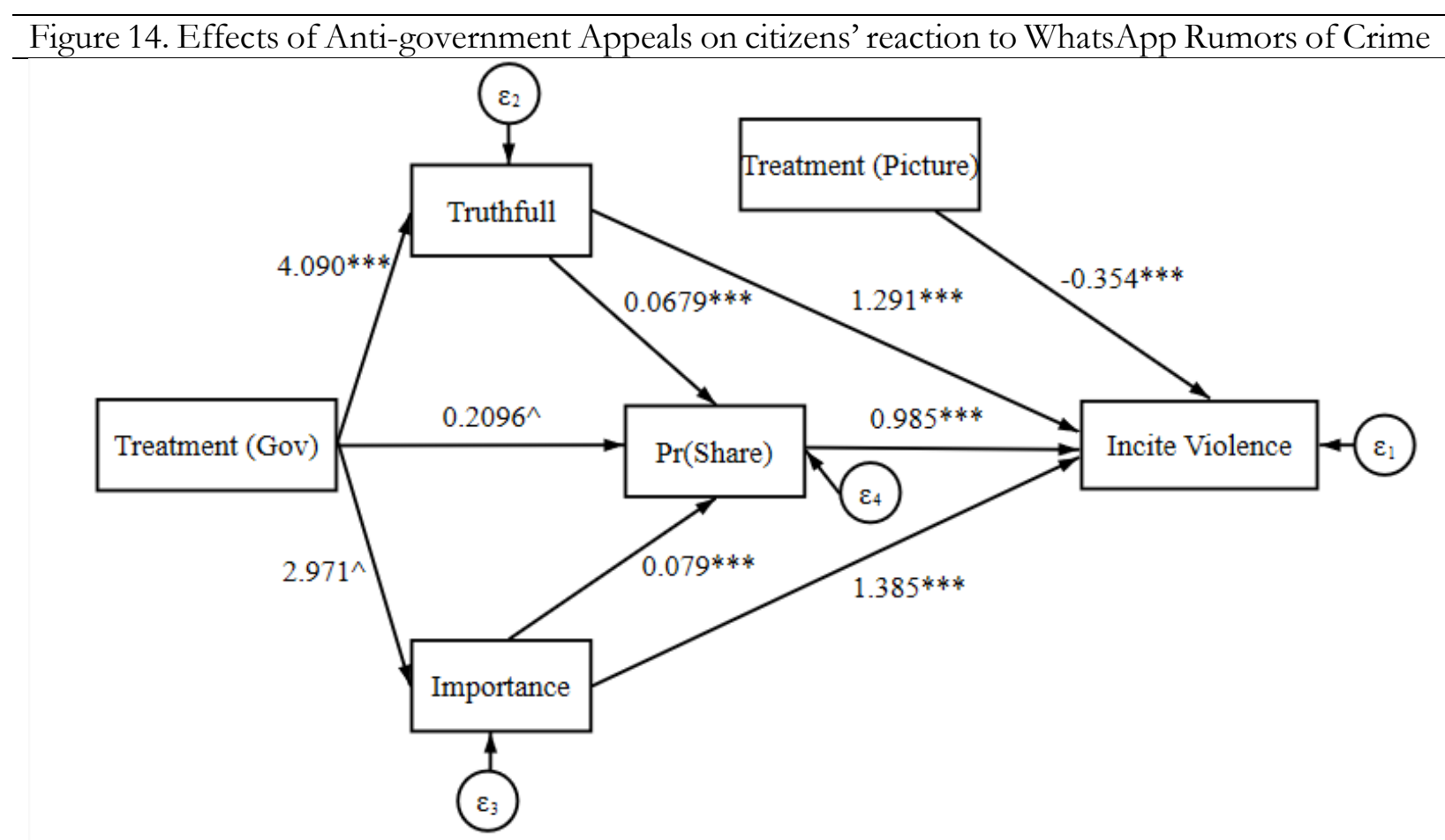

$* * * \mathrm{p}<0.01, * * \mathrm{p}<0.05, * \mathrm{p}<0.1^{\wedge} \mathrm{p}<0.1$ (one-tailed). Demographic controls and fixed effects were jointly estimated but were not included here for simplicity. Insignificant paths between the "Picture treatment" and the variables initially hypothesized to serve as mediators were omitted for parsimony as they were also insignificant.

As the diagram shows, we find evidence that appeals to the indifference and malevolence of government increase the likelihood of rumors to be perceived as credible and important by citizens. Then, we find that shifts in citizens' evaluations of rumors increase the likelihood of sharing them. Finally, we find that changes in citizens' reactions to rumors significantly increase their willingness to incite others to engage in deadly violence. While we find no evidence that rumors that include the image of criminals are perceived as more credible, important, or shareable, we do find images to increase the aggressive tendencies of those exposed to rumors about crime. 


\section{CONCLUSION}

Violence-inducing rumors circulating via WhatsApp and other messaging networks have triggered spectacular explosions of violence from India to Mexico. While understanding the forces that expose individuals to these messages is important, identifying the features that make these messages infectious and contagious is critical for our capacity to design effective interventions to stop this violence pandemic. In this paper, we have argued that, in addition to containing social and psychological components, violence-inducing rumors also contain a political element that allows them to propagate. Namely, they often include the central message they seek to convey with appeals to citizens' distrust in government authorities. These appeals, we contend, are instrumental in increasing rumors' capacity to portray themselves as credible and important. To test this claim, we designed and implemented a laboratory experiment in a rural community in Mexico in which we asked participants to report the degree to which they found a rea WhatsApp rumor known to be involved in several lynching cases as credible and important. As expected, we found evidence that appeals to the untrustworthiness of government increased the subjects' perception of the credibility and importance of violence-inducing rumors. We then find that these shifts increased participants' willingness to disseminate these dangerous messages among their networks. Importantly, we found signs that the effects of attitudes go beyond information-sharing. We found that subjects perceiving rumors as more credible, important, and sharable were also more likely to incite others to commit violence against alleged criminals when given a chance.

Although these findings support the central contention of this paper, it is crucial to acknowledge that our results are not without their limitations. First, they are constrained to the historical and geographical context in which the experiment took place. Although we consider that ours is particularly interesting for the phenomenon at hand, it would be necessary to conduct additional research to evaluate the impact of anti-governmental appeals on citizens in urban and non- 
marginalized contexts. Moreover, our study exposed participants to a very particular type of rumor about crime. While we think that the rumor studied here is quite representative of the type of rumors that have triggered collective violence around the world, future studies should investigate the capacity of the hypothesis presented here to explain the emergence of violence in other contexts. For instance, it would be interesting to see whether appeals to the indifference of the government for the health of its population increase the propagation of rumors against minorities perceived as potentially infectious. Finally, while we have proposed some variables that could mediate the effect of antigovernment appeals, testing the importance of these and other mechanisms has fallen outside of the scope of this study. More detailed experiments would be necessary to disentangle the cognitive and emotional forces that could link appeals to government distrust to citizens' willingness to disseminate dangerous rumors.

Despite these limitations, we think that this study makes valuable theoretical, practical, and methodological contributions. On the one hand, they put the spotlight on a mechanism - appeals to government distrust - known to be present in various different forms of misinformation but, until now, not incorporated in our models of the spread of violence-inducing rumors. While previous authors have incorporated the conspiracy mentality as a static force that shapes citizens' disposition to accept misinformation, we show that even when holding constant individuals baseline dispositions, rumors that preface their incitements to violence with negative appeals to government authorities tend to be more likely to propagate on the population. Training individuals to understand this strategy as a way in which those propagating medical frauds and violence attempt to persuade the public may help us prevent the spread of this type of collective violence in some of the areas in which this is most urgent (Roozenbeek and van der Linden 2019).

On the other hand, our study contributes to a growing literature interested in understanding the emergence of vigilante justice. While this is not the first time that citizens' distrust in law 
enforcement authorities has been linked with the emergence of vigilante justice, our results show that government distrust not only serves as the basis for the formation of extralegal anti-criminal organizations (Zizumbo-Colunga 2019) and as the basis of citizens' abstract sympathies for extralegal violence (Cruz and Kloppe-Santamaría 2019; Malone 2012; Seligson 2003), it also serves as the fuel that propagates citizens' deepest fears about crime and as the match that ignites the fire of extralegal violence. 


\section{REFERENCES}

Allen, Frederick. 2004. A Decent, Orderly Lynching: The Montana Vigilantes. University of Oklahoma Press.

Allport, Floyd H., and Milton Lepkin. 1945. "Wartime Rumors of Waste and Special Privilege: Why Some People Believe Them.” The Journal of Abnormal and Social Psychology 40 (1): 3-36. https://doi.org/10.1037/h0058110.

Arun, Chinmayi. 2019. "On WhatsApp, Rumours, Lynchings, and the Indian Government." SSRN Scholarly Paper ID 3336127. Rochester, NY: Social Science Research Network. https://papers.ssrn.com/abstract=3336127.

Bagozzi, Richard P. 1977. "Populism and Lynching in Louisiana." American Sociological Review 42 (2): 355-58. https://doi.org/10.2307/2094610.

Banaji, Shakuntala, Ramnath Bhat, Anushi Agarwal, Nihal Passanha, and Mukti Sadhana Pravin. 2019. "WhatsApp Vigilantes: An Exploration of Citizen Reception And Circulation Of WhatsApp Misinformation Linked To Mob Violence In India.” Monograph. London, UK: London School of Economics. https://www.lse.ac.uk/media-andcommunications/assets/documents/research/projects/WhatsApp-MisinformationReport.pdf.

Berinsky, Adam J. 2017. "Rumors and Health Care Reform: Experiments in Political Misinformation.” British Journal of Political Science 47 (2): 241-62. https://doi.org/10.1017/S0007123415000186.

Bhavnani, Ravi, Michael G. Findley, and James H. Kuklinski. 2009. "Rumor Dynamics in Ethnic Violence." The Journal of Politics 71 (3): 876-92. https://doi.org/10.1017/S002238160909077X.

Bohlken, Anjali Thomas, and Ernest John Sergenti. 2010. "Economic Growth and Ethnic Violence: An Empirical Investigation of Hindu-Muslim Riots in India." Journal of Peace Research 47 (5): 589-600. https://doi.org/10.1177/0022343310373032.

Bordia, Prashant, and Nicholas DiFonzo. 2017. "Psychological Motivations in Rumor Spread." In Rumor Mills: The Social Impact of Rumor and Legend, edited by Veronique Campion-Vincent, 87115. Routledge.

Bronstein, Michael V., Gordon Pennycook, Adam Bear, David G. Rand, and Tyrone D. Cannon. 2019. "Belief in Fake News Is Associated with Delusionality, Dogmatism, Religious Fundamentalism, and Reduced Analytic Thinking." Journal of Applied Research in Memory and Cognition 8 (1): 108-17. https://doi.org/10.1016/j.jarmac.2018.09.005.

Bruder, Martin, Peter Haffke, Nick Neave, Nina Nouripanah, and Roland Imhoff. 2013. "Measuring Individual Differences in Generic Beliefs in Conspiracy Theories Across Cultures: Conspiracy Mentality Questionnaire.” Frontiers in Psychology 4. https://doi.org/10.3389/fpsyg.2013.00225.

Buchanan, Tom, and Vladlena Benson. 2019. "Spreading Disinformation on Facebook: Do Trust in Message Source, Risk Propensity, or Personality Affect the Organic Reach of 'Fake News'?” Social Media + Society 5 (4): 205630511988865. https://doi.org/10.1177/2056305119888654.

Castillo-Claudett, Eduardo. 2000. "La Justicia En Tiempos de La Ira : Linchamientos Populares Urbanos En América Latina." Ecuador Debate. Sociopolíticas de La Pobreza y Exclusión 51: 20726.

Cheeseman, Nic, Jonathan Fisher, Idayat Hassan, and Jamie Hitchen. 2020. "Social Media Disruption: Nigeria's WhatsApp Politics.” Journal of Democracy 31 (3): 145-59. https://doi.org/10.1353/jod.2020.0037. 
Chen, Xinran, and Sei-Ching Joanna Sin. 2013. "'Misinformation? What of It?' Motivations and Individual Differences in Misinformation Sharing on Social Media." Proceedings of the American Society for Information Science and Technology 50 (1): $1-4$. https://doi.org/10.1002/meet.14505001102.

Chen, Xinran, Sei-Ching Joanna Sin, Yin-Leng Theng, and Chei Sian Lee. 2015. "Why Students Share Misinformation on Social Media: Motivation, Gender, and Study-Level Differences." The Journal of Academic Librarianship 41 (5): 583-92. https://doi.org/10.1016/j.acalib.2015.07.003.

Christian, Cornelius. 2017. "Lynchings, Labour, and Cotton in the US South: A Reappraisal of Tolnay and Beck." Explorations in Economic History 66 (October): 106-16. https://doi.org/10.1016/j.eeh.2017.08.005.

Chuai, Yuwei, and Jichang Zhao. 2020. “Anger Makes Fake News Viral Online.” ArXiv:2004.10399 [Cs], May. http://arxiv.org/abs/2004.10399.

Coan, Travis, Jennifer L. Merolla, Elizabeth J. Zechmeister, and Danie Zizumbo-Colunga. 2020. "Emotional Responses Shape the Substance of Information Seeking under Conditions of Threat." Political Research Quarterly.

Cohen, Mollie J, Noam Lupu, Elizabeth J Zechmeister, United States, Agency for International Development, and Latin American Public Opinion Project. 2017. The Political Culture of Democracy in the Americas, 2016/17: A Comparative Study of Democracy and Governance.

Comercio, El. 2017. "Multitud Intenta Linchar a Pareja Por Falsa Acusación En WhatsApp En Brasil.” El Comercio, April 6, 2017. http:/ /www.elcomercio.com/tendencias/multitudlinchamiento-pareja-mensaje-whatsapp.html.

Coviello, Lorenzo, Yunkyu Sohn, Adam D. I. Kramer, Cameron Marlow, Massimo Franceschetti, Nicholas A. Christakis, and James H. Fowler. 2014. "Detecting Emotional Contagion in Massive Social Networks.” PLOS ONE 9 (3): e90315. https://doi.org/10.1371/journal.pone.0090315.

Cruz, José Miguel, and Gema Kloppe-Santamaría. 2019. "Determinants of Support for Extralegal Violence in Latin America and the Caribbean." Latin American Research Review 54 (1): 50-68. https://doi.org/10.25222/larr.212.

DiFonzo, Nicholas, and Prashant Bordia. 2002. "Corporate Rumor Activity, Belief and Accuracy." Public Relations Review 28 (1): 1-19. https://doi.org/10.1016/S0363-8111(02)00107-8.

Druckman, James N., and Cindy D. Kam. 2011. "Students as Experimental Subjects: A Defense of the 'Narrow Data Base." In Cambridge Handbook of Experimental Political Science, by James N. Druckman, Donald P. Green, James H. Kuklinski, and Arthur Lupia. Cambridge University Press.

Effron, Daniel A., and Medha Raj. 2020. "Misinformation and Morality: Encountering Fake-News Headlines Makes Them Seem Less Unethical to Publish and Share." Psychological Science 31 (1): 75-87. https://doi.org/10.1177/0956797619887896.

Evangelista, Rafael, and Fernanda Bruno. 2019. "WhatsApp and Political Instability in Brazil: Targeted Messages and Political Radicalisation.” Internet Policy Review 8 (4): 1-23. https://doi.org/10.14763/2019.4.1434.

Fan, Rui, Jichang Zhao, Yan Chen, and Ke Xu. 2014. “Anger Is More Influential than Joy: Sentiment Correlation in Weibo.” PLOS ONE 9 (10): e110184. https://doi.org/10.1371/journal.pone.0110184.

Farooq, Gowhar. 2018. "Politics of Fake News: How WhatsApp Became a Potent Propaganda Tool in India.” Media Watch 9 (1). https://doi.org/10.15655/mw/2018/v9i1/49279.

Finocchiaro, Maurice A. 2015. “The Argument Form 'Appeal to Galileo': A Critical Appreciation of Doury’s Account.” Informal Logic 35 (3): 221-72. https://doi.org/10.22329/il.v35i3.4306. 
Fuentes-Diaz, Antonio. 2004. "Linchamientos en Mexico." Ecuador Debate 61: 259-60.

Godoy, Angelina Snodgrass. 2006. Popular Injustice: Violence, Community, and Law in Latin America. 1 edition. Stanford, Calif: Stanford University Press.

Goldstein, Daniel M. 2003. "In Our Own Hands': Lynching, Justice, and the Law in Bolivia." American Ethnologist 30 (1): 22-43.

2004. The Spectacular City: Violence and Performance in Urban Bolivia. Durham, NC: Duke University Press Books.

Greenhill, Kelly M., and Ben Oppenheim. 2017. "Rumor Has It: The Adoption of Unverified Information in Conflict Zones.” International Studies Quarterly 61 (3): 660-76. https://doi.org/10.1093/isq/sqx015.

Guess, Andrew, Jonathan Nagler, and Joshua Tucker. 2019. "Less than You Think: Prevalence and Predictors of Fake News Dissemination on Facebook." Science Advances 5 (1): 1-8. https://doi.org/10.1126/sciadv.aau4586.

Halpern, Daniel, Sebastián Valenzuela, James Katz, and Juan Pablo Miranda. 2019. "From Belief in Conspiracy Theories to Trust in Others: Which Factors Influence Exposure, Believing and Sharing Fake News." In Social Computing and Social Media. Design, Human Bebavior and Analytics, edited by Gabriele Meiselwitz, 217-32. Lecture Notes in Computer Science. Cham: Springer International Publishing. https://doi.org/10.1007/978-3-030-21902-4_16.

Handy, Jim. 2004. "Chicken Thieves, Witches, and Judges: Vigilante Justice and Customary Law in Guatemala." Journal of Latin American Studies 36 (3): 533-61.

Hepworth, Joseph T., and Stephen G. West. 1988. "Lynchings and the Economy: A Time-Series Reanalysis of Hoyland and Sears (1940)." Journal of Personality and Social Psychology 55 (2): 239_ 46.

Hern, Alex. 2020. "WhatsApp to Impose New Limit on Forwarding to Fight Fake News." The Guardian, April 7, 2020, sec. Technology. https://www.theguardian.com/technology/2020/apr/07/whatsapp-to-impose-new-limiton-forwarding-to-fight-fake-news.

Hinton, Nicole, Daniel Montalvo, Arturo Maldonado, Mason Moseley, and Daniel ZizumboColunga. 2014. "Crime and Violence across the Americas." In The Political Culture of Democracy in the Americas, 2014: Democratic Governance across 10 Years of the AmericasBarometer, edited by Elizabeth J. Zechmeister, 3-21. Vanderbilt University.

Horn, Heather. 2016. "Where Does Fear of Refugees Come From?” The Atlantic, April 27, 2016. https://www.theatlantic.com/international/archive/2016/04/refugees-crimerumors $/ 480171 /$.

Hovland, Carl Iver, and Robert R. Sears. 1940. "Minor Studies of Aggression: VI. Correlation of Lynchings with Economic Indices." The Journal of Psychology 9 (2): 301-10. https://doi.org/10.1080/00223980.1940.9917696.

Hsu, Wen-Yi, and Chaoyun Liang. 2007. "The Influence of Source Credibility, User's Affection and Involvement on College Student's Belief toward Internet Rumors." Journal of Educational Media \& Library Sciences 45 (1): 99-120.

Huddy, Leonie, Stanley Feldman, and Erin Cassese. 2007. "On the Distinct Political Effects of Anxiety and Anger." In The Affect Effect: Dynamics of Emotion in Political Thinking and Behavior, by W. Russell Neuman, George E. Marcus, Michael MacKuen, and Ann N. Crigler, 1st ed., 202-31. University Of Chicago Press.

Imhoff, Roland, Michał Bilewicz, Katja Hanke, Dennis T. Kahn, Naomi Henkel-Guembel, Slieman Halabi, Tal-Shani Sherman, and Gilad Hirschberger. 2017. "Explaining the Inexplicable: 
Differences in Attributions for the Holocaust in Germany, Israel, and Poland." Political Psychology 38 (6): 907-24. https://doi.org/10.1111/pops.12348.

Imhoff, Roland, Lea Dieterle, and Pia Lamberty. 2020. "Resolving the Puzzle of Conspiracy Worldview and Political Activism: Belief in Secret Plots Decreases Normative but Increases Nonnormative Political Engagement." Social Psychological and Personality Science, March, 1948550619896491. https://doi.org/10.1177/1948550619896491.

Iyengar, Shanto, and Douglas S. Massey. 2019. "Scientific Communication in a Post-Truth Society." Proceedings of the National Academy of Sciences 116 (16): 7656-61. https://doi.org/10.1073/pnas.1805868115.

Johnson, David Kyle. 2018. "Galileo Gambit.” In Bad Arguments, by Robert Arp, Steven Barbone, and Michael Bruce, 152-56. John Wiley \& Sons, Ltd. https://doi.org/10.1002/9781119165811.ch27.

Jolley, Daniel, and Jenny L. Paterson. 2020. "Pylons Ablaze: Examining the Role of 5G COVID-19 Conspiracy Beliefs and Support for Violence.” British Journal of Social Psychology 59 (3): 628640.

Lai, Kaisheng, Xiling Xiong, Xiaoya Jiang, Meiqi Sun, and Lingnan He. 2020. "Who Falls for Rumor? Influence of Personality Traits on False Rumor Belief." Personality and Individual Differences 152. https://doi.org/10.1016/j.paid.2019.109520.

Landrum, Asheley R., and Alex Olshansky. 2019. "The Role of Conspiracy Mentality in Denial of Science and Susceptibility to Viral Deception about Science." Politics and the Life Sciences 38 (2): 193-209. https://doi.org/10.1017/pls.2019.9.

Lazer, David M. J., Matthew A. Baum, Yochai Benkler, Adam J. Berinsky, Kelly M. Greenhill, Filippo Menczer, Miriam J. Metzger, et al. 2018. “The Science of Fake News.” Science 359 (6380): 1094-96. https://doi.org/10.1126/science.aao2998.

Lerner, Jennifer S., and Dacher Keltner. 2001. "Fear, Anger, and Risk." Journal of Personality and Social Psychology 81 (1): 146-59.

Lupia, Arthur. 1994. "Shortcuts Versus Encyclopedias: Information and Voting Behavior in California Insurance Reform Elections.” The American Political Science Review 88 (1): 63-76. https://doi.org/10.2307/2944882.

Malone, Mary Fran T. 2012. "Support for Extralegal Justice." In The Rule of Law In Central America: Citizens' Reactions to Crime and Punishment, 1 edition, 93-126. New York, NY: Bloomsbury Academic.

Marcus, George E., W. Russell Neuman, and Michael MacKuen. 2000. Affective Intelligence and Political Judgment. 1st ed. University Of Chicago Press.

Martínez, Marcos. 2018. "Cómo un mensaje de WhatsApp llevó a un pequeño pueblo de México a quemar vivos a dos hombres." BBC News Mundo, November 12, 2018, sec. América Latina. https://www.bbc.com/mundo/noticias-america-latina-46178633.

Martínez-Cantera, Ángel L. 2018. "Los rumores de WhatsApp que acaban en linchamientos de inocentes en India." El País, July 3, 2018, sec. Internacional. https://elpais.com/internacional/2018/07/03/actualidad/1530626284_146875.html.

Mendoza, Carlos. 2009. Linchamientos : Barbarie O Justicia Popular? FLACSO Guatemala.

Miranda, Boris. 2018. "La Ola de Cadenas Falasas de WhatsApp Sobre Secuestros de Niños Que Provocaron El Linchamiento de Una Persona En Bogotá.” BBC News Mundo, October 31, 2018, sec. America Latina. https://www.bbc.com/mundo/noticias-america-latina-46051654.

Moscovici, Serge. 1987. “The Conspiracy Mentality." In Changing Conceptions of Conspiracy, edited by Carl F. Graumann and Serge Moscovici, 151-69. Springer Series in Social Psychology. New York, NY: Springer. https://doi.org/10.1007/978-1-4612-4618-3_9. 
Moura, Mauricio, and Melissa R. Michelson. 2017. "WhatsApp in Brazil: Mobilising Voters through Door-to-Door and Personal Messages." Internet Policy Review 6 (4): 1-18. https://doi.org/10.14763/2017.4.775.

Newsom, S W B. 2002. “Stevens' Cure: A Secret Remedy.” Journal of the Royal Society of Medicine 95 (9): 463-67.

Nyhan, Brendan, and Jason Reifler. 2010. "When Corrections Fail: The Persistence of Political Misperceptions.” Political Behavior 32 (2): 303-30. https://doi.org/10.1007/s11109-010-91122.

Oster, Emily. 2004. "Witchcraft, Weather and Economic Growth in Renaissance Europe." Journal of Economic Perspectives 18 (1): 215-228.

Pennycook, Gordon, Tyrone D. Cannon, and David G. Rand. 2018. "Prior Exposure Increases Perceived Accuracy of Fake News.” Journal of Experimental Psychology. General 147 (12): 186580. https://doi.org/10.1037/xge0000465.

Pennycook, Gordon, and David G. Rand. 2020. "Who Falls for Fake News? The Roles of Bullshit Receptivity, Overclaiming, Familiarity, and Analytic Thinking." Journal of Personality 88 (2): 185-200. https://doi.org/10.1111/jopy.12476.

Peregil, Francisco. 2014. "Argentina se estremece ante la irrupción de varios linchamientos a ladrones." El País, April 4, 2014. http://internacional.elpais.com/internacional/2014/04/04/actualidad/1396625984_568501. html.

Petrović, Boban, Janko Međedović, Olivera Radović, and Sanja Radetić Lovrić. 2019. "Conspiracy Mentality in Post-Conflict Societies: Relations With the Ethos of Conflict and Readiness for Reconciliation." Europe's Journal of Psychology 15 (1): 59-81. https://doi.org/10.5964/ejop.v15i1.1695.

Pezzo, Mark V., and Jason W. Beckstead. 2006. "A Multilevel Analysis of Rumor Transmission: Effects of Anxiety and Belief in Two Field Experiments." Basic and Applied Social Psychology 28 (1): 91-100. https://doi.org/10.1207/s15324834basp2801_8.

Phartiyal, Sankalp, Subrat Patnaik, and David Ingram. 2018. "When a Text Can Trigger a Lynching: WhatsApp Struggles with Incendiary Messages in India.” Reuters, June 25, 2018. https://in.reuters.com/article/us-facebook-india-whatsapp-fake-news-idINKBN1JL0OW.

Radnitz, Scott, and Patrick Underwood. 2017. "Is Belief in Conspiracy Theories Pathological? A Survey Experiment on the Cognitive Roots of Extreme Suspicion." British Journal of Political Science 47 (1): 113-29. https://doi.org/10.1017/S0007123414000556.

Roozenbeek, Jon, and Sander van der Linden. 2019. "Fake News Game Confers Psychological Resistance Against Online Misinformation.” Palgrave Communications 5 (1): 1-10. https://doi.org/10.1057/s41599-019-0279-9.

Rosnow, Ralph L. 1980. "Psychology of Rumor Reconsidered.” Psychological Bulletin 87 (3): 578-91. https://doi.org/10.1037/0033-2909.87.3.578.

—. 1991. "Inside Rumor: A Personal Journey." American Psychologist 46 (5): 484-96. https://doi.org/10.1037/0003-066X.46.5.484.

Seligson, Mitchell A. 2003. "Public Support for Due Process Rights: The Case of Guatemala." Journal of the Southwest 45 (4): 557-94.

Senechal de la Roche, Roberta. 2001. "Why Is Collective Violence Collective?” Sociological Theory 19 (2): $126-44$.

Smink, Veronica. 2019. "La conmoción en Argentina por el linchamiento del padre de un joven falsamente acusado de violación.” BBC News Mundo, March 29, 2019, sec. América Latina. https://www.bbc.com/mundo/noticias-america-latina-47754925. 
Sniderman, Paul M., Richard A. Brody, and Philip Tetlock. 1993. Reasoning and Choice: Explorations in Political Psychology. Cambridge University Press.

Stieglitz, Stefan, and Linh Dang-Xuan. 2013. "Emotions and Information Diffusion in Social Media-Sentiment of Microblogs and Sharing Behavior." Journal of Management Information Systems 29 (4): 217-48. https:/ / doi.org/10.2753/MIS0742-1222290408.

Taber, Charles S, and Milton Lodge. 2006. "Motivated Skepticism in the Evaluation of Political Beliefs." American Journal of Political Science 50: 755--769.

Tajfel, Henri, and John C. Turner. 1986. “The Social Identity of Intergroup Behavior.” In Psychology of Intergroup Relations, by William G. Austin and Stephen Worchel, 7-24. Chicago: NelsonHall.

Tolnay, Stewart E, and Elwood Meredith Beck. 1995. A Festival of Violence: An Analysis of Southern Lynchings, 1882-1930. Urbana Champaign: University of Illinois Press.

Vinck, Patrick, Phuong N Pham, Kenedy K Bindu, Juliet Bedford, and Eric J Nilles. 2019. "Institutional Trust and Misinformation in the Response to the 2018-19 Ebola Outbreak in North Kivu, DR Congo: A Population-Based Survey." The Lancet Infectious Diseases 19 (5): 529-36. https://doi.org/10.1016/S1473-3099(19)30063-5.

Walker, Charles J., and Carol A. Beckerle. 1987. "The Effect of State Anxiety on Rumor Transmission.” Journal of Social Behavior \& Personality 2 (3): 353-60.

Ward, Megan. 2020. "Walls and Cows: Social Media, Vigilante Vantage, and Political Discourse." Social Media + Society 6 (2): 2056305120928513. https://doi.org/10.1177/2056305120928513.

Wisniewski, Mary. 2014. "Kevin Trudeau Jailed for 10 Years over Weight-Loss Book Claims." Reuters, March 18, 2014, Online edition. https://in.reuters.com/article/usa-trudeaupitchman/update-3-u-s-tv-pitchman-trudeau-sentenced-to-10-years-in-prisonidINL2N0ME1LF20140317.

Wolverton, Colleen, and David Stevens. 2019. "The Impact of Personality in Recognizing Disinformation.” Online Information Review 44 (1): 181-91. https:/ / doi.org/10.1108/OIR-042019-0115.

Wood, Michael J., Karen M. Douglas, and Robbie M. Sutton. 2012. "Dead and Alive: Beliefs in Contradictory Conspiracy Theories." Social Psychological and Personality Science 3 (6): 767-73. https://doi.org/10.1177/1948550611434786.

Zerega, Georgina. 2019. "Los linchamientos en México, al borde de triplicarse en un año.” El País, May 23, 2019, sec. Mexico. https://elpais.com/internacional/2019/05/23/mexico/1558565136_836230.html.

Zizumbo-Colunga, Daniel. 2017. "Community, Authorities, and Support for Vigilantism: Experimental Evidence.” Political Behavior 39 (4): 989-1015. https://doi.org/10.1007/s11109-017-9388-6. . 2019. "Confronting Crime by Ourselves: Trust in Neighbors, Authorities and Anti-Criminal Organization.” Latin American Research Review 54 (3). 


\section{APPENDIX}

\section{APPENDIX 1:}

The following WhatsApp message inspired our design. This message was detected as circulating in social networks soon after the lynchings that took place in central Mexico (Puebla and Hidalgo) and were described in the start of the paper.

https://lopezdoriga.com/nacional/mexico/las-noticias-falsas-que-propiciaron-linchamientos-enmexico/

The red square is the exact section that we used to design our treatment.

Alerta

2 niños encontrados ya sin vida les sacaron los Organos, ya varias muchachas

de Prepa y Secundaria desaparecidas. La muchacha que fue desaparecida el

Viernes fue encontrada ya hoy sin vida y en la misma situación, sin órganos, hay

que poner un alto y estar alerta de todo... EL GOBIERNO HACE COMO QUE NO

PASA NADA, por eso no sale en las noticias ni en el periodico, es mas importante

"quedar bien" CUIDEMONOS ENTRE NOSOTROS... Pasalo no te lo quedes, este

mensaje puede cambiar la historia.....

Avisen a todos sus contactos que quiten la foto de su perfil de WhatsApp donde estan sus hijos it it

porque salio en el periodico que estan checando Jovenes y niños para robar

porfavor avisa a tu gente.... Comparte!!!!!! Urge esto está pasando

Es el relato de un caso real que sucediola semana pasada y que un amigo 10

está compartiendo:

La semana pasada me llegó este mensaje y me pesa en mi conciencia no

habérselos contado.

A una amiga mía la durmieron en el baño de Cinepolis y le robaron todo y no

recuerda nada, solo que una Sra. le dio a oler un perfume.

También yo fui abordado ayer en la tarde cerca de las 3:30 pm. en el

estacionamiento del Sam 's por 2 hombres que me preguntaron cual era el tipo

de perfume que yo usaba.

Luego me preguntaron si me gustaría oler un tipo de perfume sensacional que

ellos estaban vendiendo a un precio de oferta.

Probablemente yo habría aceptado si no hubiese recibido este email, algunas

semanas atrás, avisándome sobre EL GOLPE DEL PERFUME.

Los hombres permanecieron entre los autos estacionados, imagino que

esperando que alguien mas apareciese.

Pare a una Sra. que iba en dirección a ellos y la previne, me habían avisado que

en los centros comerciales o estacionamientos hay gente que te abordan para

ofrecerte OLER EL PERFUME que están vendiendo pero que en realidad NO es

nerfume. FS AXTFR 


\section{APPENDIX 2}

The second task was inspired on a journalistic note reporting the process of formation of a lynching soon after the case narrated in the first page of the paper.

https://www.excelsior.com.mx/nacional/se-gesta-en-redes-sociales-otro-linchamiento-enhidalgo/1262143

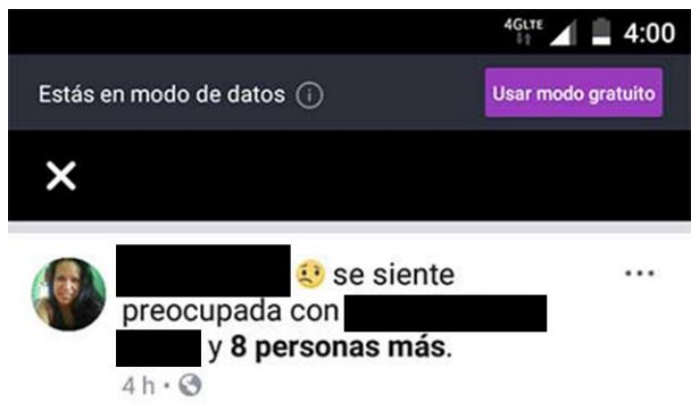

Por favor papás esten alertas. Anda un carro desconocido aki en el coyol chapulhuacan con placas de California es una mujer y un hombre kien lo conduce tengan cuidado

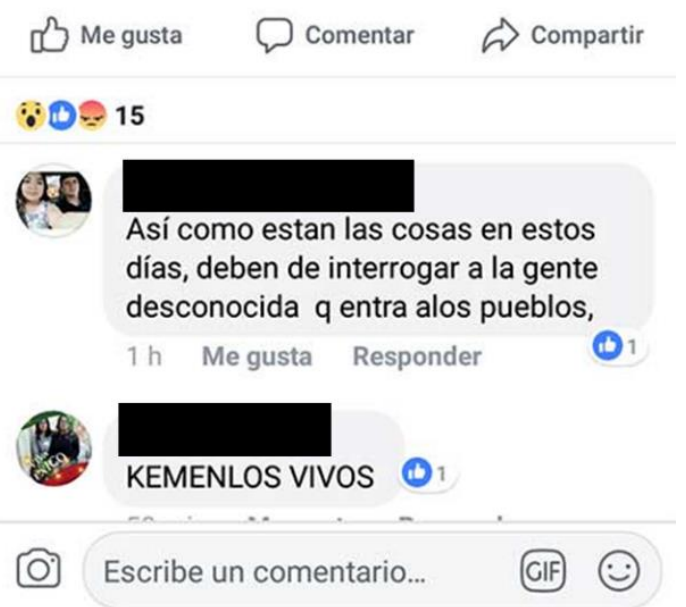




\section{APPENDIX 3}

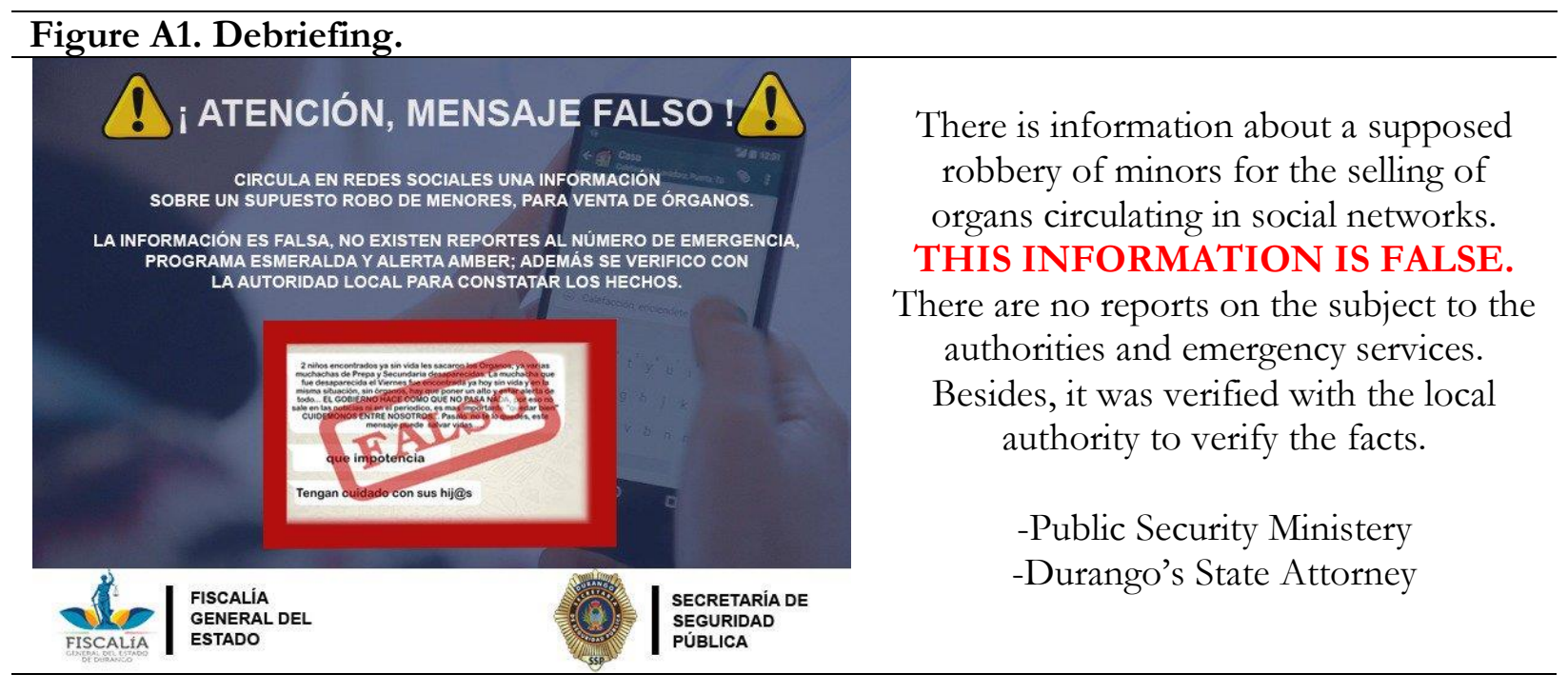

